\title{
Renewable Waste-to-Energy in Southeast Asia: Status, Challenges, Opportunities, and Selection of Waste-to-Energy Technologies
}

\author{
Maw Maw Tun ${ }^{1,2, * \mathbb{D}}$, Petr Palacky ${ }^{1}$, Dagmar Juchelkova ${ }^{1} \mathbb{D}$ and Vladislav Sít ař ${ }^{3}$ \\ 1 Faculty of Electrical Engineering and Computer Science, VŠB-Technical University of Ostrava, \\ 17. listopadu 2172/15, 70800 Ostrava-Poruba, Czech Republic; petr.palacky@vsb.cz (P.P.); \\ dagmar.juchelkova@vsb.cz (D.J.) \\ 2 Department of Technical and Vocational Education and Training, Ministry of Education, Office No. 21, \\ Naypyitaw 15011, Myanmar \\ 3 Faculty of Mechanical Engineering (FME), J. E. Purkyně University in Ústí nad Labem, \\ 40096 Ústí nad Labem, Czech Republic; Vladislav.Sitar@ujep.cz \\ * Correspondence: maw.maw.tun.st@vsb.cz or bdtmawmawtun@gmail.com; Tel.: +95-976-764-9249
}

Received: 15 September 2020; Accepted: 13 October 2020; Published: 19 October 2020

\begin{abstract}
Rapid urban population growth that boosts increased waste generation and electricity demand has led to a possible alternative waste-to-energy solution in Southeast Asia. Despite some issues related to the development of the waste-to-energy sector such as public perception, all stakeholder involvement, public-private partnerships, funding, and climate factors, some Southeast Asian countries have made a reasonably successful step toward the developed technologies. Therefore, this study aimed to highlight an overview of the waste-to-energy sector in Southeast Asian countries to specify the status, challenges, opportunities, and selection of the technologies suited for the specific country. In order to achieve this aim, the study collected, synthesized, and evaluated data about waste resources, current waste management, waste-to-energy utilization, and its potential in the region based on published research papers and policy reports. It was found that the major waste-to-energy technologies in the region are incineration, landfills with gas capture, and anaerobic digestion. The total quantity of the waste-to-energy capacity from landfill biogas plants, incineration plants, and other waste-to-energy practices in the region accounts for over $323 \mathrm{MW}$ at present and is expected to grow to double its current size by 2022. Meanwhile, by 2030, the realizable generation potential from renewable municipal waste in six Southeast Asian countries (Indonesia, Malaysia, Philippines, Singapore, Thailand, and Vietnam) amounts to 17.26 terawatt-hours (TWh). The study also specifies the requirements and considerations for the selection of waste-to-energy technologies, as well as the dimensions related to the development of the technologies. Additionally, four major aspects-technical, financial, environmental, and social and political-regarding the challenges and opportunities for the development of these technologies are considered. The challenges and opportunities related to the development of waste-to-energy in the region reveal how to overcome the drawbacks and to grasp the benefits at present and in the near future. Finally, the study is concluded with suggestions for the selection of the technologies in the region.
\end{abstract}

Keywords: energy from waste; renewable energy; waste management; waste-to-energy technologies; Southeast Asia

\section{Introduction}

As the world hurtles toward its urban future, the amount of municipal solid waste (MSW), one of the most important by-products of an urban lifestyle, is growing even faster than the rate of 
urbanization [1]. The amount of MSW generation of the cities around the world might increase from 1.3 billion tons per year to 2.2 by 2025, and waste generation rates might double over the next two decades in developing countries [1,2].

The East Asia and Pacific (EAP) region has a higher urban population than other regions, and it is projected to reach 1229 million in 2025, up from 777 million in 2012 (Figure 1). Despite the lower per capita waste generation rate in the region compared to the Organization for Economic Co-operation and Development (OECD) in 2012, it will be increased by 60\% in 2025. Since the Southeast Asian countries (Brunei Darussalam, Cambodia, Indonesia, Laos PDR, Malaysia, Myanmar, Philippines, Singapore, Thailand, and Vietnam) belong to the East Asia and Pacific region, the annual urban population of these countries, as per the World Bank Report [1], is expected to grow considerably by 2025, hence increasing the amount of annual waste generation. However, only 30-70\% of waste can be collected in most developing countries, including Myanmar, Laos PDR, and Cambodia, whereas developed countries have a $76-100 \%$ collection efficiency $[1,3]$.

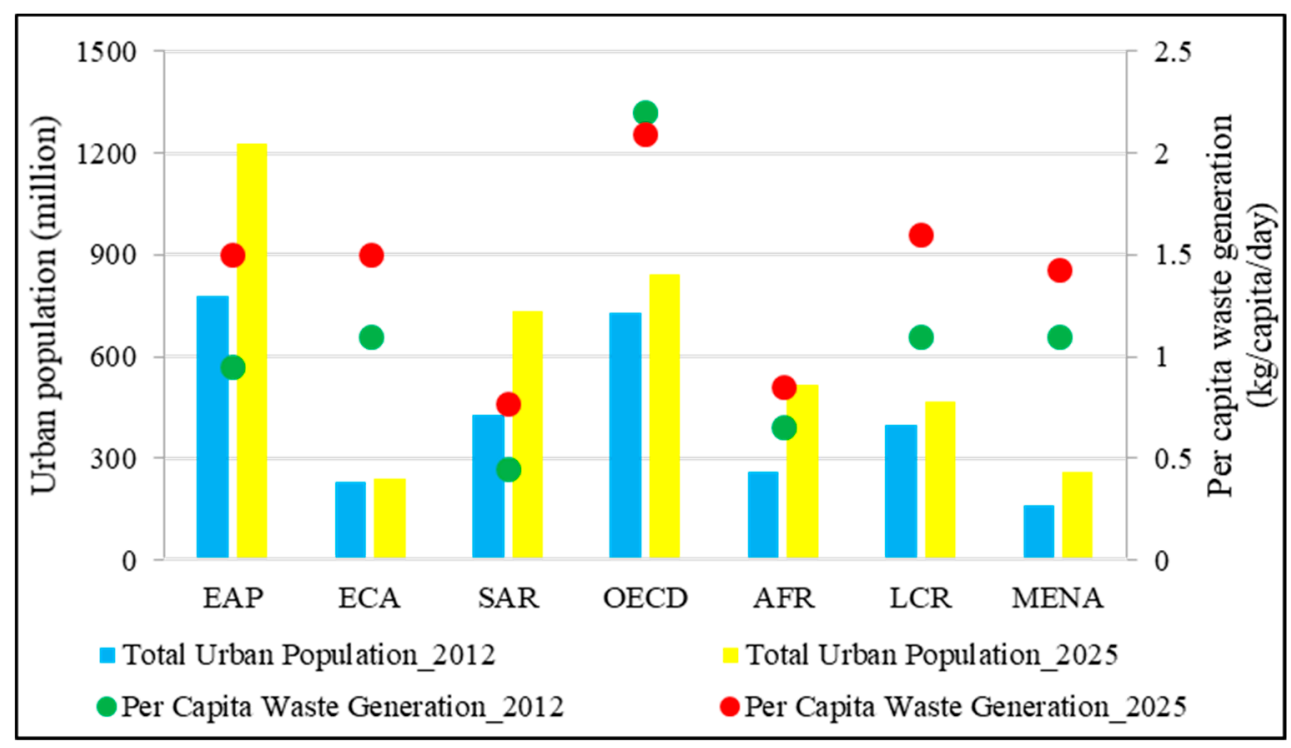

Figure 1. A comparison of urban population and per capita waste generation in world regions between the year 2012 and 2025 [1]. Note: EAP: East Asia and Pacific region; ECA: Europe and Central Asia region; SAR: South Asia region; OECD: Organization for Economic Co-operation and Development; AFR: Africa region; LCR: Latin America and the Caribbean region; MENA: Middle East and North Africa region.

With accelerated urbanization, economic growth, and changing lifestyles [4], Southeast Asia's urban population is projected to rise to nearly 400 million by 2030 [5]. Additionally, the growth of electricity demand is also prompting countries to more than double generation capacity by 2040 [5]. The projected rise of energy demand in Southeast Asia will have a considerable effect on $\mathrm{CO}_{2}$ emissions, which are projected to rise from $3.5 \%$ today to $5 \%$ by 2030 [6,7]. Figure 2 shows the access to electricity, per capita electricity consumption, and per capita $\mathrm{CO}_{2}$ emission in Southeast Asian countries. Per capita electricity consumption in the majority of the countries is below $2500 \mathrm{kWh}$ per capita, and their per capita $\mathrm{CO}_{2}$ emissions are below $4500 \mathrm{~kg}$. The average carbon emission in Southeast Asian countries has been increased by over $5 \%$ due to the fast economic growth in the region $[8,9]$. Though Singapore, Malaysia, Brunei Darussalam, and Thailand have already allowed $100 \%$ access to their electricity, other countries like Philippines and Vietnam are projecting to reach this 100\% access by 2020 [9]. 


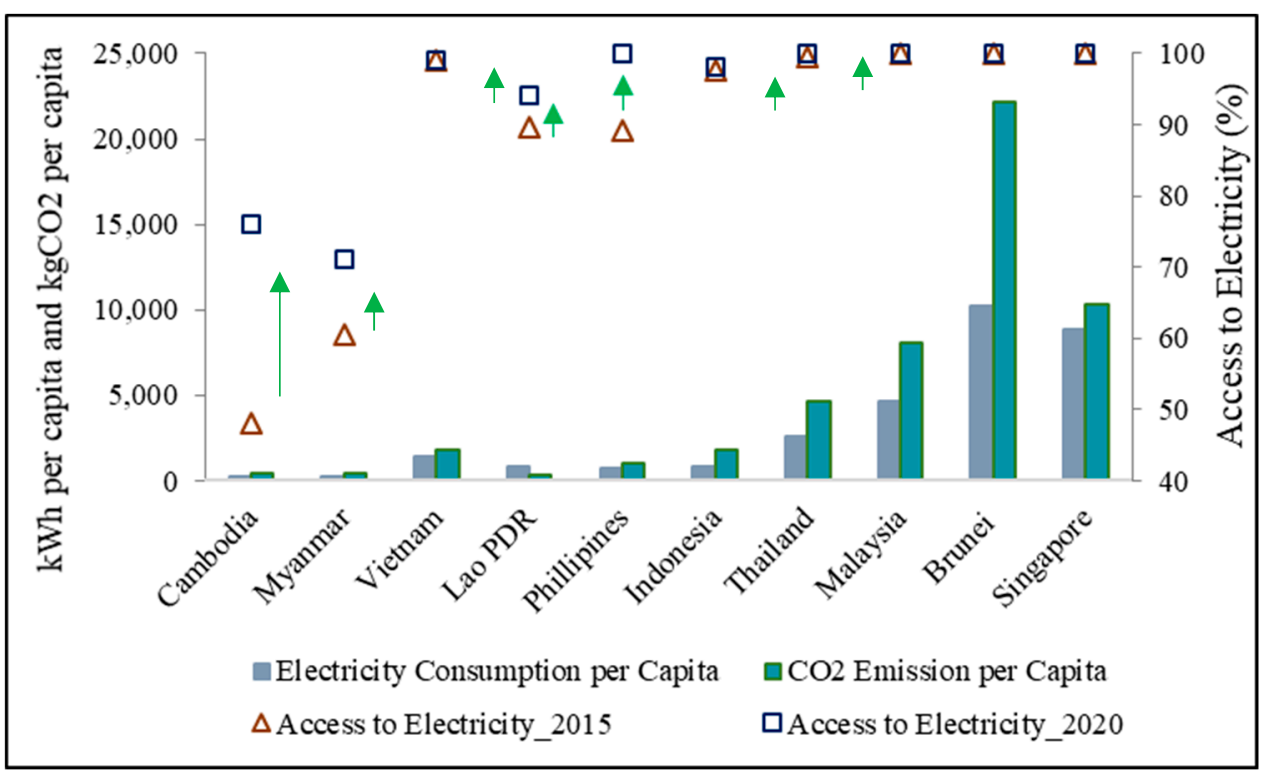

Figure 2. Access to electricity (2015 and 2020), electricity consumption per capita (2014), and $\mathrm{CO}_{2}$ emission per capita (2014) in Southeast Asian countries [9].

The total electricity generation from the renewables and non-renewables in the Southeast Asia region amounted to approximately 856 terawatt-hours (TWh) in 2014, out of which $20 \%$ came from renewable energy $(74.1 \%$ hydropower, $12.6 \%$ biofuels, $11.5 \%$ geothermal, $1.2 \%$ solar photovoltaic (PV), and $0.6 \%$ wind) [10]. As shown in Figure 3, the bioenergy demand in non-OECD Asia is projected to grow dramatically by 2035. It has been observed that the demand for biofuels in this region will potentially rise from 2 million tons of oil equivalent (Mtoe) in 2009 to over 30 Mtoe in 2035, whereas the demand for biomass and waste might be increased by approximately 50\% from 480 Mtoe in 1990 to over 700 Mtoe in 2035.

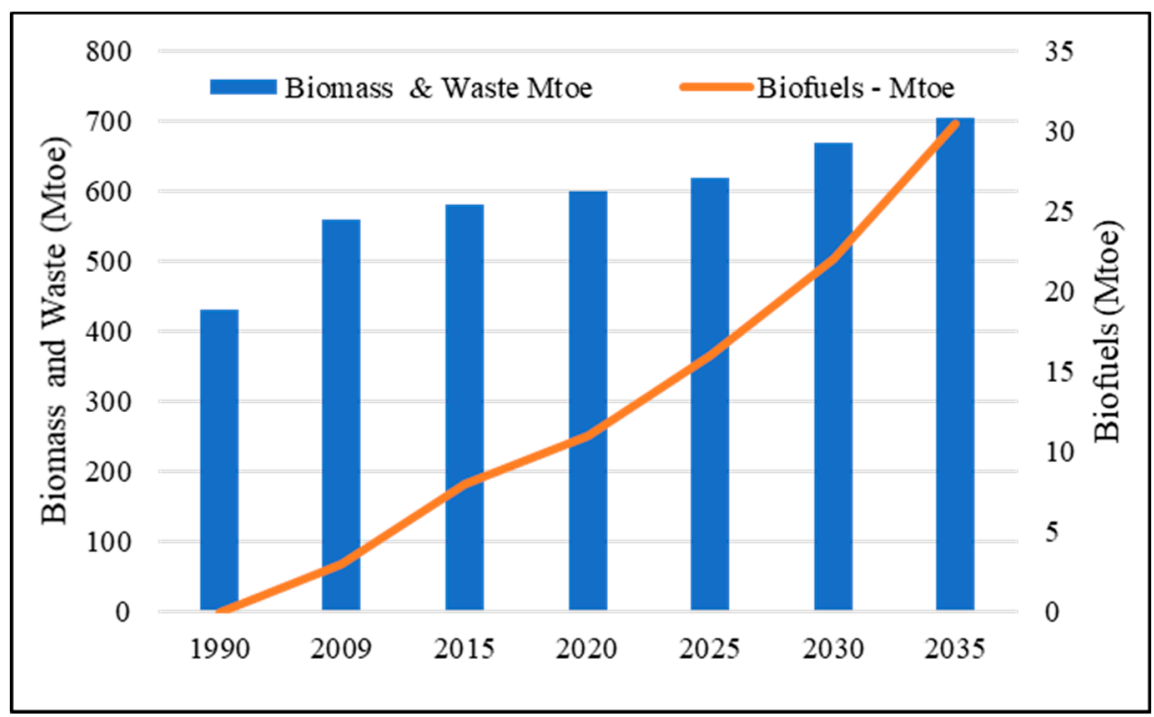

Figure 3. Actual and projected bioenergy demand in non-OECD Asia, 1990-2035 [11].

Waste to Energy in Asia

Due to the potential depletion of fossil fuel and climate change, Southeast Asian countries have looked to renewable and alternative energies to reduce greenhouse gas emissions and other environmental impacts from the energy sector [9]. On the other hand, the growing urban population will accelerate the amount of annual waste generation (approximately 97 million tons per year in 
2015 to 165 million tons per year by 2025) in these countries [1,12], requiring significant investment in waste management to cope with the increase in waste [5]. The rapid urban population growth that has boosted waste generation and electricity demand has led to a possible alternative solution in Southeast Asia. Waste-to-energy - a catch-all for different technologies that allows countries to get rid of waste and generate electricity at the same time-is one obvious and quick solution to these two needs [5]. Therefore, the technologies constitute a meeting point for the waste management and energy sectors to work together and benefit from each other in the most efficient manner [2].

Actually, waste-to-energy is also a kind of biomass energy, offering benefits not only to minimize the waste crisis but also to meet the actual fossil-free high demand [2] and to reduce the greenhouse gas emissions and climate change impacts [13]. Nowadays, it has become a type of renewable energy utilization that can provide environmental and economic benefits in the world [13]. Currently, there are more than 2200 thermal waste treatment plants all over the world with a total capacity of 300 million tons per year, and it has been estimated that more than 600 new waste-to-energy facilities will be built with a capacity of 170 million tons per year by 2025 [2,14]. China had 7.3 gigawatts of energy production across 339 power plants in 2017, and they are expecting to grow to 10 gigawatts and 600 plants by 2020 [5]. The selection of the most suitable technology is based on social, economic, and technical factors, as well as environmental strategies to ensure the best outcomes [2]. In Europe, the most widespread options for upgrading waste treatment are the incineration of grey waste and anaerobic digestion (AD), often combined with the composting of the separated fraction of organic waste [3]. When it comes to waste-to-energy plants, there are regional preferences-gasification is in favor in South Asia, while grate incineration is generally used in Europe [3].

As described in Figure 4, the most common waste-to-energy technologies in the developing world include [2,15-17];

(i) Thermal conversion (incineration, pyrolysis, gasification, and plasma gasification).

(ii) Biochemical conversion (fermentation, anaerobic digestion, landfills with gas capture, and microbial fuel cell).

(iii) Chemical conversion (esterification).

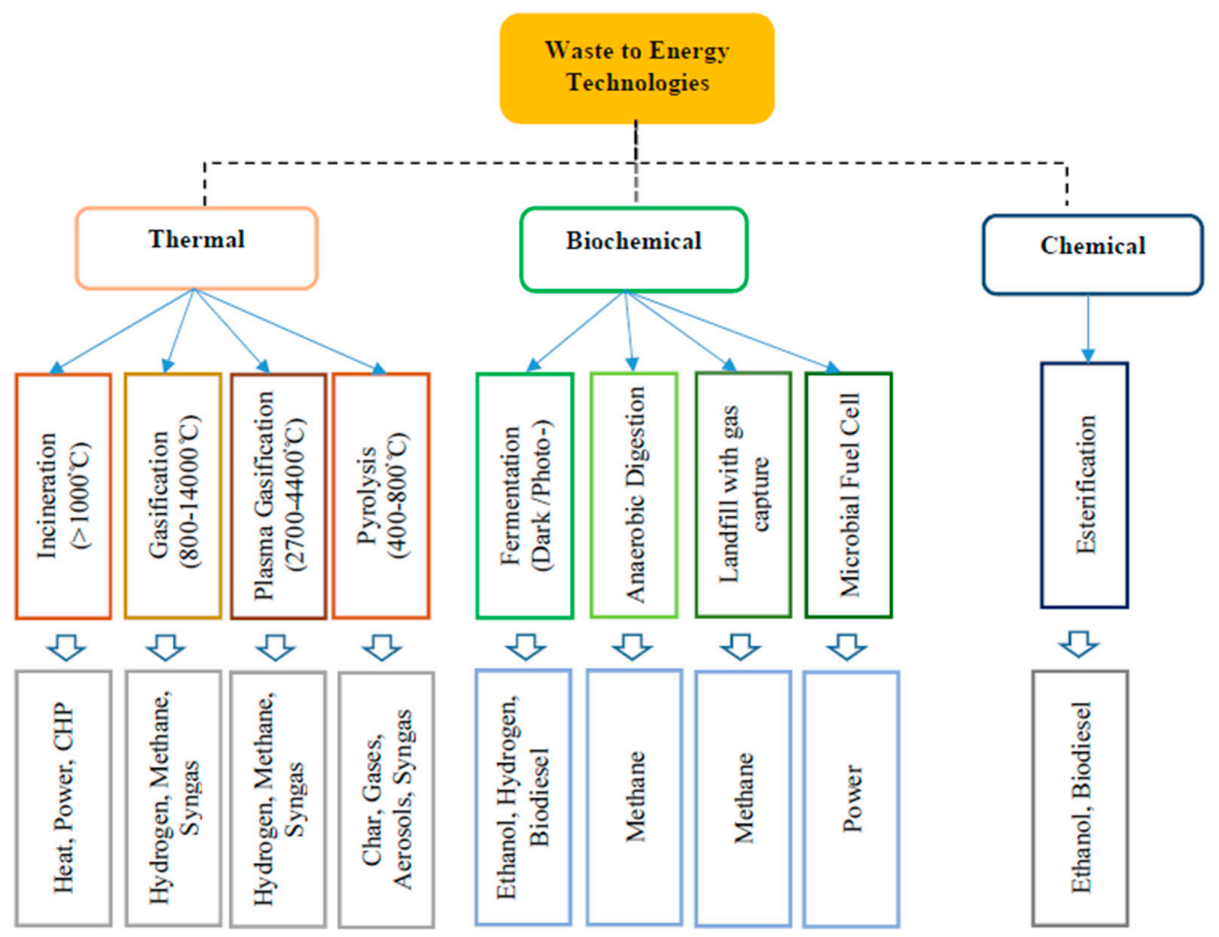

Figure 4. Most common waste-to-energy technologies [15,16]. Note: CHP is Combined Heat and Power. 
The future trends in the area are in the direction of biological hydrogen production (photo-biological process and dark fermentation), bio-electrochemical processes (microbial fuel cells (MFCs), microbial electrolysis cells (MECs), and hydrothermal carbonization [2].

Technologies such as the incineration process have been advantageous, not only for reductions in the mass and volumes of initial waste but also for energy recovery and the reduction of land use for landfills [18]. When incinerated, waste can be reduced to $80-85 \%$ by weight and $95-96 \%$ by volume [19]. Additionally, incineration can be considered as a net greenhouse gas (GHG) reducer if GHG reductions, achieved by accounting for waste-to-energy, exceed GHG emissions [20].

Nowadays, waste-to-energy plants are most often tailor made, depending on very specific local requirements. Thus, construction costs vary widely, and a typical range in Europe is around 500-700 Euro per ton per year in installed capacity, not including the cost for the site and project development [21]. Globally, the estimated cost for the waste-to-energy technologies in the lower middle income countries is in the range of 40-100 US dollar (USD) per ton for incineration and 20-80 USD per ton for anaerobic digestion (AD), while the estimated cost in high income countries is in the range of 70-200 USD per ton for incineration and 65-150 USD per ton for AD [1]. Figure 5 illustrates that the application of waste-to-energy technologies in low-income and lower middle-income countries is merely at the development stage compared to the upper middle-income and high-income countries, which are actively using these technologies.

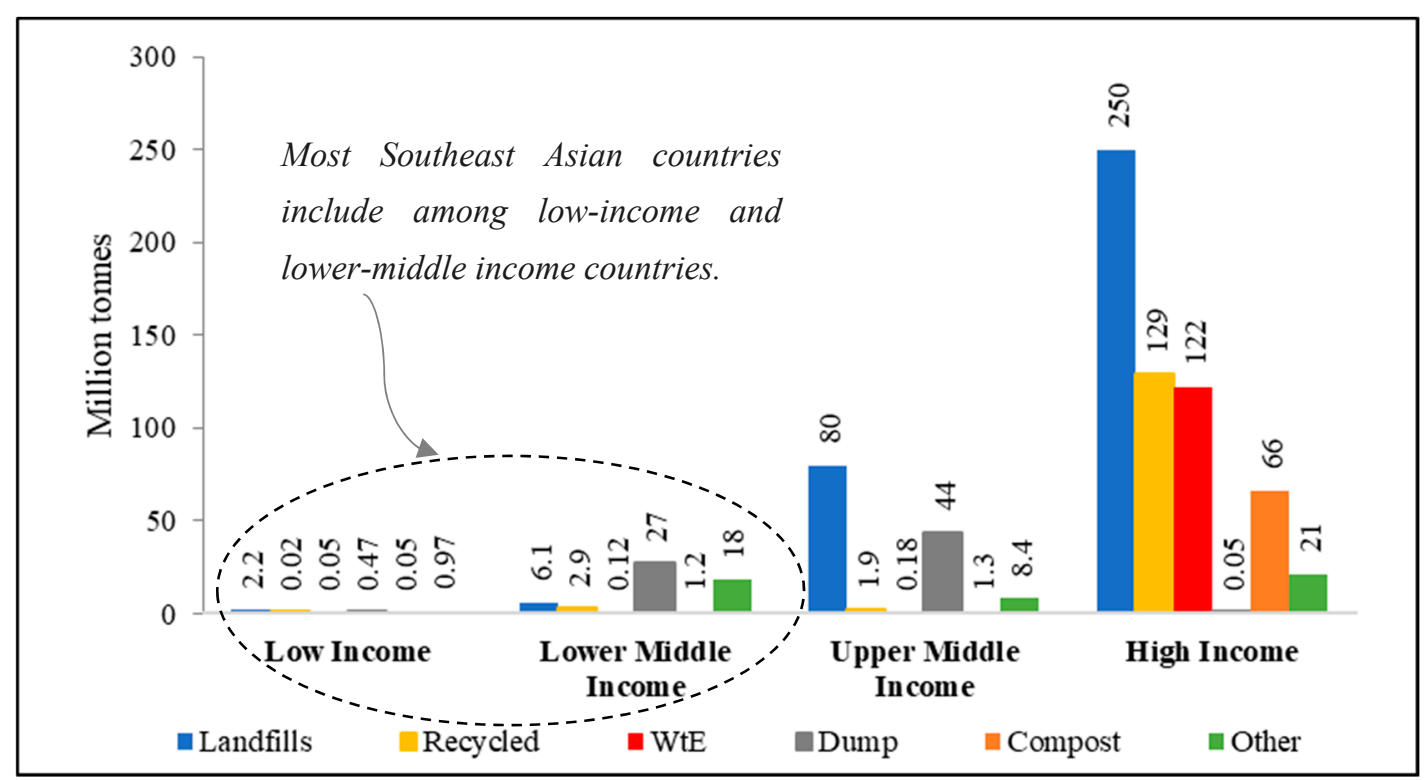

Figure 5. Waste disposal method by income [1].

In Figure 6a, the forecast shows that, globally, the growth of waste-to-energy technologies is projected to reach 24.5 million USD in 2024 from 2.1 million USD in 2010. Meanwhile, the regional market investment in incineration in Asia will have grown from 616 million USD in 2006 to 6463 million USD in 2021, representing an investment increase by a factor of 10 (Figure 6b). Additionally, the Asia-Pacific waste-to-energy market is projected to grow at an annual rate of over $15 \%$ and will reach a value of 13.66 billion USD by 2023 [22]. Thus, it is seen that the waste-to-energy sector in Asia has a great potential in technological transfer and investment $[15,23]$. 


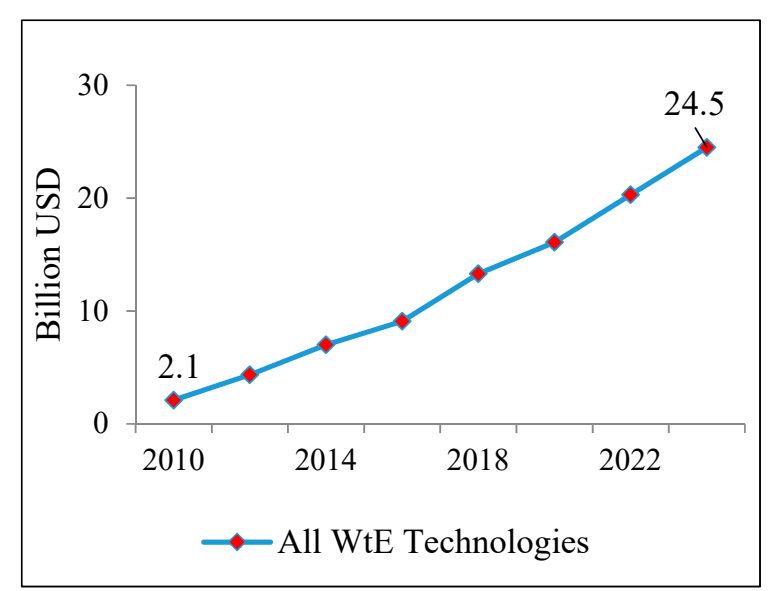

(a)

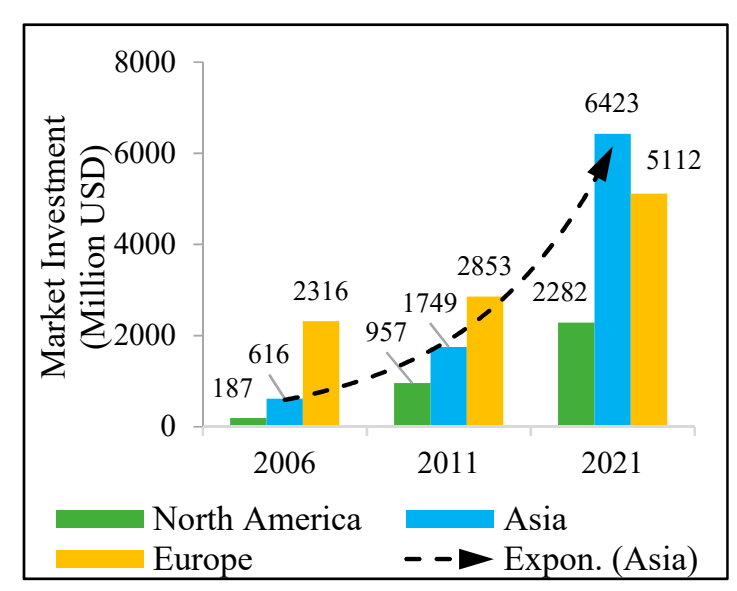

(b)

Figure 6. (a) Growth forecast of all waste-to-energy technologies globally (b) regional market for incineration $[15,23]$. Note: WtE: Waste to Energy.

Currently, waste incineration is uncommon in developing countries, and, generally, it is not successful or experiences financial and operational difficulties due to the high capital cost of the plant, operation and maintenance costs, the high moisture content of MSW, and the need for sorting facilities and pretreatment processes $[1,18]$. However, energy-oriented conversion technologies for waste-to-fuel and waste-to-energy have been well-developed around the world to create energy/fuel from waste, reduce dependency on fossil fuel, reduce land use for waste disposal, and ensure socio-economic and environmental benefits [24-26]. Though there is still a long way until a global sustainable waste management strategy is achieved [15], developing countries can learn the lessons about and gain technology transfers from the waste-to-energy technologies and waste management practices in developed countries.

Nowadays, most Southeast Asian countries are facing several issues related to waste management, such as the increasing annual waste generation that has required more waste disposal sites, the scarcity of land areas, environmental pollution, and growth in energy demand $[4,5,7,27]$. Since these issues are especially important to be tackled in Southeast Asia, waste-to-energy technologies can play an essential role in sustainable waste management and the relief of environmental matters $[17,25,26]$. Meanwhile, some aspects such as regulation, finance, and technological suitability should be carefully considered to develop the waste-to-energy sector in the region $[2,12,15,16,18,24]$.

Several studies have, to a reasonable extent, overviewed, analyzed, and evaluated the waste management and waste-to-energy sectors in Southeast Asian countries [1,28], but most have focused on the waste-to-energy sector in specific countries such as Thailand [29,30], Malaysia [31-33], Vietnam [17], and Myanmar [13]. Despite some issues such as public perception, public-private partnerships, all stakeholder involvement, funding, and climate factors, some Southeast Asian countries have made a reasonably successful step toward waste-to-energy technologies. Therefore, this study aimed to highlight an overview of the waste-to-energy sector in Southeast Asian countries to specify the status, challenges, opportunities, and selection of technologies suited for a specific country. As a major contribution, the study especially focuses on waste-to-energy alternatives, their potential, and the feasibility to implement them in the Southeast Asian countries where important data are not available.

The study consists of five major sections: introduction, methodology, results and discussion, recommendation, and conclusion. The introduction section describes an overview of waste management and waste-to-energy in Asian countries, whereas the methodology section specifies how the study was carried out. The results and discussion section conveys information about waste management, the status of waste-to-energy technologies, the requirements and considerations for the selection of the technologies, and the dimensions, challenges, and opportunities in Southeast Asia. Then, 
the study provides recommendations for the way forward regarding the waste-to-energy sector before a brief conclusion.

\section{Methodology}

Since most countries in Southeast Asia are developing countries, their MSW management is not well-developed. Meanwhile, their waste-to-energy sectors are also at the development stage. As a result, there are some difficulties in collecting updated data about their MSW management systems and waste-to-energy sectors; most of these data are not fully accessible. Therefore, the data related to the study were collected, to a feasible extent, from previous research papers [13,17,28-38], review papers [9,39-41], policy reports by the World Bank [1], the United Nations Environment Programme [12,42], the International Energy Agency [3,7], the International Renewable Energy Agency [43,44], the World Energy Council [15], and other accessible reports. Then, the study synthesized, analyzed, and evaluated data about waste resources, current waste management, and waste-to-energy utilization in Southeast Asian countries in order to highlight a comparison of MSW management systems and the status of waste-to-energy processes among the countries. The study also specifies the requirements and considerations for the selection of waste-to-energy technologies, as well as the dimensions regarding the development of these technologies. Additionally, four major aspects—-technical, financial, environmental, and social and political—regarding the challenges and opportunities for the development of waste-to-energy technologies are described. Finally, the study provides suggestions for the selection of waste-to-energy technologies in the region.

\section{Results and Discussion}

\subsection{MSW Management in Southeast Asia}

The generation and characteristics of waste mainly rely on population growth, the rate of urbanization, the degree of industrialization, income level, consumption habits, local climate, and economic policies [2,15]. The major portion of waste composition in Southeast Asia countries is composed of organic waste, followed by plastic and paper. Typical waste composition in Southeast Asia comprises $51 \%$ organic waste, $12.9 \%$ paper, $7.2 \%$ plastics, $4 \%$ glass, $3.3 \%$ metal, and $19.6 \%$ other. (Figure 7). The average per capita waste generation in the region accounts for approximately $1 \mathrm{~kg}$ per capita per day [1].

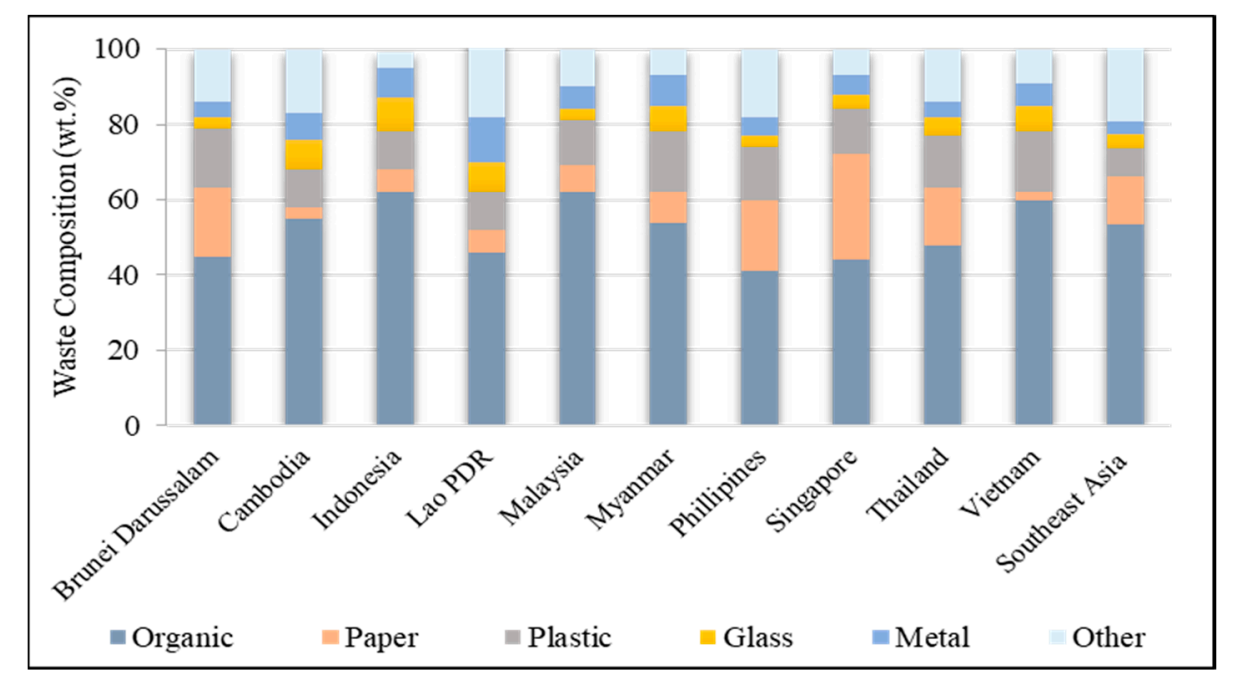

Figure 7. A comparison of waste composition in Southeast Asian countries [1,12].

Table 1 shows some brief demographic context, waste generation, and waste management data in Southeast Asian countries. The urban population in most of these countries has below $50 \%$ of the total waste, most from low-income and lower middle-income countries. Low economic development 
countries regionally experience lower per capita waste generation rates, accounting for below $1 \mathrm{~kg}$ per capita per day. Additionally, source segregation and collection rates-at below $50 \%$ and $70 \%$, respectively, compared to the rates of the developed countries-are affected by this low economic development [1]. In average, Southeast Asian countries practice 5\% compost, $9 \%$ incineration, $59 \%$ solid waste disposal, and $27 \%$ other, including recycling, waste-to-energy, and other waste disposal methods [12]. More details about the demographic context and waste management of each Southeast Asian country are described below.

\section{(a) Brunei Darussalam}

Brunei Darussalam has 423,188 residents, and its urban population was 77\% of the total in 2015 . Along with the waste generation of $0.87 \mathrm{~kg}$ per capita per day [1], the total annual waste generation in 2015 amounted to 210,000 tons per year, and the collection efficiency was $90 \%$ [12,42]. The country disposes of the majority of waste to disposal sites, but it only composts $2 \%$ of its waste [1]. With costly waste management infrastructure and limited land area, the country has encountered a lack of capacity in the design, implementation, and monitoring of policies, programs, and projects [42]. However, the country is developing projects based on a public-private partnership (PPP) mechanism for the waste management sector [42]. It is expected to contribute $10 \%$ renewable energy share in power generation by 2035, excluding hydropower [45]. The potential share of renewable energy, in total, of the primary energy supply has been projected to reach 4\% in 2025 and 7\% in 2030 [44].

\section{(b) Cambodia}

Cambodia has 15,577,899 residents, and its urban population was 21\% of the total in 2015 [12]. Along with the waste generation of $0.6 \mathrm{~kg}$ per capita per day [1], the total annual waste generation in 2014 amounted to 1,089,000 tons per year, and the collection efficiency was $80 \%$ [12,42]. The recycling sector contributes $20 \%$ of the total waste generation. Despite a lack of policies and programs that address significant reduction of MSW, the country is preparing an integrated solid waste management strategy for the future development of the MSW management sector [42]. However, there is still limited awareness and behavior of people related to the concept of sustainable cities/green cities [42]. The country has set a target of $27 \%$ emission reduction by 2030 relative to business-as-usual (BAU) in the energy industry [41]. The potential share of renewable energy in total primary energy supply is projected to reach $35 \%$ in 2025 and $44 \%$ in 2030 [44].

\section{(c) Indonesia}

Indonesia has 255,993,674 residents, and its urban population was 54\% in 2015 [12]. Along with the waste generation of $0.52 \mathrm{~kg}$ per capita per day [1], the total annual waste generation in 2012 amounted to $22,500,060$ tons per year, and the collection efficiency ranged from $56 \%$ to $75 \%[1,12,42]$. Indonesia has set major policies, programs, strategies, and projects for MSW [42], and it has successfully implemented the concept of an MSW management system despite it currently being not well-implemented and enforced at all government levels. Twelve waste-to-energy plants are expected to be completed in 2022 and produce 234 megawatts (MW) of electricity [22]. However, there is still a lack of knowledge and skills at the technology, financial, and institutional levels with high investment costs and limited project support [42]. The target for biomass and waste policy in Indonesia is expected to achieve 810 MW by 2025 [15] and to contribute a $23 \%$ non-renewable energy share in the energy mix in 2025 [45]. The country has targeted the achievement of a $29-41 \%$ emission reduction by 2030 by means of the promotion of clean and renewable energy and energy conservation [41].

\section{(d) Laos PDR}

Laos PDR has 6,802,023 residents, and its urban population was 39\% in 2015 [12]. Along with the waste generation of $0.7 \mathrm{~kg}$ per capita per day [1], the total annual waste generation in 2015 amounted 
to 77,000 tons per year, and the collection efficiency was in the range of $40-70 \%$ [12,42]. Regarding the MSW management system, the country has well-set environmentally sustainable city guidelines related to the future development of the MSW sector [42]. Incineration as a waste-to-energy technology option currently contributes $2 \%$ out of the total waste disposal methods. However, the country still lacks comprehensive policies, programs, equipment, and technology for MSW management, in addition to a limited awareness and behavior of people regarding the concept of sustainable cities/green cities [42]. Laos PDR is projected to achieve a 30\% renewable energy share of total energy consumption by 2025, excluding hydropower [45], and 10\% biofuel use in transport sectors by 2025 [41].

\section{(e) Malaysia}

Malaysia has 30,331,007 residents, and its urban population was 75\% in 2015 [12]. Along with the waste generation of $1.52 \mathrm{~kg}$ per capita per day [1], the total annual waste generation in 2015 amounted to $10,680,000$ tons per year, and the collection efficiency was above $70 \%$ [12,42]. Coordination among relevant local, state, and federal agencies in the waste sector is a key prerequisite for effective waste management [42]. The incineration plant in Selangor has a capacity of 1000 tons per day or $8.9 \mathrm{MW}$ of electricity generation, and, while in operation with $70 \%$ of its actual capacity, it can generate $5 \mathrm{MW}$ of electricity [12]. The total capacity of operating landfill biogas plants registered under the feed-in-tariff (FiT) scheme from 2012 to 2018 was around $13.8 \mathrm{MW}$, and the planned capacity in three more new projects is about 11.7 MW [32]. Located in Tanah Merah, Negeri Sembilan, the first waste-to-energy plant project is planned to facilitate 1000 metric tons of solid waste daily and to produce 20-25 MW of electricity for powering 25,000 households [22]. However, the country lacks a strong understanding of waste composition, an adequate awareness of the 3Rs (Reduce, Reuse and Recycle) practice, and the budget for raising awareness programs [42]. The country will increase the capacity of renewables to 2.08 GW by 2020 [39] and 4 GW renewable energy in installed capacity by 2030, which excludes hydropower [45]. Additionally, the country has set a target to achieve a 35\% GHG reduction by 2030 from the 2005 level—or up to $45 \%$ with international support [39].

\section{(f) Myanmar}

Myanmar has 53,897,154 residents, and its urban population was 34\% in 2015 [12]. Along with the waste generation of $0.44 \mathrm{~kg}$ per capita per day [1], the total annual waste generation in 2015 amounted to $1,130,040$ tons per year, but the collection efficiency remained below $50 \%$ [12,42]. The recycling sector contributes 5\% in Yangon City [13]. Despite the policies and programs set for MSW, the country has been weak in developing an action plan and projects [42]. Additionally, the country lacks knowledge, experts, and skilled personnel, and it has had few projects and a limited awareness of people related to the concept of sustainable cities/green cities [42]. The capacity of the first waste-to-energy plant operated in Yangon in 2017 was $0.76 \mathrm{MW}$ [46]. The country has set a target of a 15\%-20\% renewable energy share in its installed capacity by 2030, excluding hydropower [45]. Moreover, the country has planned to reduce its GHG emissions by $16 \%$ below the BAU level by 2020 and to stabilize its GHG emissions by around 2030 without reaching a peak limit [39].

\section{(g) Philippines}

Philippines has 100,998,376 residents in 2015, and its urban population was 44\% [12]. Along with a waste generation of $0.5 \mathrm{~kg}$ per capita per day [1], the total annual waste generation in 2015 amounted to $14,400,000$ tons per year, and the collection efficiency ranged from $40 \%$ to $90 \%$, depending on the city $[12,42]$. Though the country has set MSW policies and programs, the regulations related to different MSW components need to be integrated and improved [42]. The informal private sector is, in a major way, involved in collection, transportation, and disposal in areas other than the metropolitan areas [42]. Due to high investment cost for MSW management, the country has limited projects and awareness of people concerning the concept of sustainable cities/green cities [42]. The biomass and waste policy 
target in Philippines has been set to achieve 267 MW by 2030 [15] and 15 GW of installed capacity in 2030 [45]. The country has also planned to reduce $70 \%$ of its $\mathrm{CO}_{2}$ emission by 2030 relative to its BAU scenario [41].

\section{(h) Singapore}

Singapore has 5,540,000 residents, with a 100\% urban population in 2015 [12]. Along with a waste generation of $1.49 \mathrm{~kg}$ per capita per day [1], the total annual waste generation in 2015 amounted to $7,670,000$ tons per year. The amount of the organic waste is 1,520,000 tons per year, and the collection efficiency is above $90 \%$ [12,42]. The country has long-been a regional leader in waste-to-energy development that is currently aiming to reduce the average daily amount of waste sent to Semakau landfill by 30\% [22]. Currently, the country's solid waste disposal infrastructure consists of four waste-to-energy plants: Tuas (47.8 MW), Senoko (55 MW), Tuas South (132 MW), and Keppel Seghers Tuas Plant (KSTP) (22 MW), in addition to the Semakau Landfill [22,47-49]. The country's biggest constraint is its amount of land, considering the growth of waste generation and technological options [42]. The largest waste-to-energy plant (moving grate system) has a capacity of 4300 tons of mixed MSW per day [16]. The country has set a target to achieve a $36 \%$ emission intensity reduction by 2030 from its 2005 level [41]. Additionally, the potential share of renewable energy in total primary energy supply has been projected to reach $3 \%$ in 2025 and $4 \%$ in 2030 [44].

\section{(i) Thailand}

Thailand has $67,959,259$ residents, and its urban population was $50 \%$ in 2015 [12]. Along with the waste generation of $1.76 \mathrm{~kg}$ per capita per day, the total annual waste generation in 2015 amounted to $26,850,000$ tons per year, and the collection efficiency was above $80 \%$ [12,24]. Though the country has set policies, regulatory frameworks, programs, and plans, there is a need for cost-effective technology for biomass utilization and sustainable financial and technical resources for MSW management [42]. The 10-year alternative energy development plan (2012-2021) is aimed to boost alternative energy usage (waste-to-energy) up to $25 \%$ of overall usage by increasing from $44.324 \mathrm{MW}$ of its current capacity to $160 \mathrm{MW}$ of power and 100 kilotons of oil equivalent (ktoe) of thermal power (current capacity, landfill gas: 22.23 MW; incineration and gasification: $20.06 \mathrm{MW}$; biogas: $2.034 \mathrm{MW}$; thermal: 78.59 ktoe; biomass: $1.28 \mathrm{ktoe}$; and refuse derived fuel (RDF): $77.31 \mathrm{ktoe}$ ) [50]. The country has set a target to achieve a 30\% renewable energy share in total energy consumption by 2036, excluding hydropower [45], and a $20 \%$ GHG reduction by 2030 relative to BAU—and up to $25 \%$ with international assistance [41].

\section{(j) Vietnam}

Vietnam has a total population of 91,700,000 residents, with a 34\% urban population in 2015 [12]. Along with the waste generation of $1.46 \mathrm{~kg}$ per capita per day, the total annual waste generation in 2015 amounted to $12,800,000$ tons per year, and the collection efficiency was in the range of $80-82 \%$ [12,42]. The country has developed a regulatory framework with an integrated solid waste management strategy, but it still lacks financial resources for implementing interventions and investing in GHG reduction projects in the waste sector [42]. Attracting investor interest from China, Japan, and other countries [22], the Ho Chi Minh City Municipality has released a set of criteria for investing in waste-to-energy projects that can process domestic waste up to 9300 tons per day [22]. Additionally, the government has set a high electricity purchasing price for waste-to-energy of up to USD 10.05 cents per kWh, which is even higher than prices for wind and solar power [22]. The country has targeted to achieve a $27 \mathrm{GW}$ renewable energy installation in 2030 (excluding hydropower) [45] and an 8\% GHG emission reduction—or $25 \%$ with international support—by 2030 relative to BAU [41].

\subsection{Status of Waste-to-Energy Energy and Biomass Energy in Southeast Asian Countries}

Table 2 shows the status of waste-to-energy and biomass energy in Southeast Asian countries. The status of the technologies in most Southeast Asian countries is at an emerging stage. However, 
in the near future, the development of waste-to-energy technologies could be seen to be comparatively widespread across the region due to the promotion of renewable energy supplies in the region, particularly in Indonesia, Malaysia, Thailand, and Singapore. For instance, all twelve waste-to-energy plants in Indonesia are expected to produce $234 \mathrm{MW}$ of electricity in 2022. In Malaysia, the current installed capacity from incineration and landfills is $18.8 \mathrm{MW}$. Its overall waste-to-energy potential is 400 MW. In Thailand, the total capacity of the current waste-to-energy potential is $43.324 \mathrm{MW}$ and it targeted to reach $160 \mathrm{MW}$ by 2021 . Overall, the total amount of capacity from landfill biogas plants, incineration plants, anaerobic digestion, and gasification in the region is over $323 \mathrm{MW}$ at present and is expected to reach to $700 \mathrm{MW}$ by 2022. Meanwhile, by 2030, the realizable generation potential from renewable municipal waste in six Southeast Asian countries (Indonesia, Malaysia, Philippines, Singapore, Thailand, and Vietnam) will be 17.26 TWh. 
Table 1. Demographic context, waste generation, and waste management in Southeast Asian countries $[1,12,42,46,51]$.

\begin{tabular}{|c|c|c|c|c|c|c|c|c|c|c|c|}
\hline \multicolumn{2}{|c|}{ Description } & $\begin{array}{c}\text { Brunei } \\
\text { Darussalam }\end{array}$ & Cambodia & Indonesia & Laos & Malaysia & Myanmar & Philippines & Singapore & Thailand & Vietnam \\
\hline \multicolumn{2}{|l|}{ Population (2015) } & 423,188 & $15,577,899$ & $255,993,674$ & $6,802,023$ & $30,331,007$ & $53,897,154$ & $100,998,376$ & $5,540,000$ & $67,959,259$ & $91,700,000$ \\
\hline \multicolumn{2}{|l|}{ Urban Population } & $77 \%$ & $21 \%$ & $54 \%$ & $39 \%$ & $75 \%$ & $34 \%$ & $44 \%$ & $100 \%$ & $50 \%$ & $34 \%$ \\
\hline \multicolumn{2}{|c|}{ Per Capita GDP (USD) (2015) } & $31,164.6$ & 1162.9 & 3331.7 & 2134.7 & 9955.2 & 1287.4 & 3001.0 & $55,646.6$ & 5840.0 & 2085.1 \\
\hline \multicolumn{2}{|c|}{$\begin{array}{l}\text { Waste Generation (tons/year) } \\
\text { (2015) }\end{array}$} & 210,000 & $\begin{array}{c}1,089,000 \\
(2014)\end{array}$ & $\begin{array}{l}22,500,060 \\
(2012)\end{array}$ & 77,000 & $10,680,000$ & $1,130,040$ & $14,400,000$ & $7,670,000$ & $26,850,000$ & $12,800,000$ \\
\hline \multicolumn{2}{|c|}{$\begin{array}{l}\text { Per Capita Waste Generation } \\
\text { (kg/capita/day) }\end{array}$} & 0.87 & 0.6 & 0.52 & 0.7 & 1.52 & 0.44 & 0.5 & 1.49 & 1.76 & 1.46 \\
\hline \multicolumn{2}{|l|}{ Source Segregation } & $<50 \%$ & $<50 \%$ & $<50 \%$ & $<50 \%$ & $<50 \%$ & $50 \%$ & $50-70 \%$ & $<70 \%$ & $<50 \%$ & $<50 \%$ \\
\hline \multicolumn{2}{|l|}{ Collection Rate } & $90 \%$ & $80 \%$ & $56-75 \%$ & $40-70 \%$ & $>70 \%$ & $<50 \%$ & $40-90 \%$ & $>90 \%$ & $>80 \%$ & $80-82 \%$ \\
\hline \multicolumn{2}{|c|}{ Reused and Utilized } & na & na & $7 \%$ & na & na & na & na & na & $17.80 \%$ & na \\
\hline Recycling & $\%$ & na & $20 \%$ & $7 \%$ & $9 \%$ & $5 \%$ & $5 \%$ & $28 \%$ & $47 \%$ & $14 \%$ & $8.20 \%$ \\
\hline Compost & $\%$ & $2 \%$ & na & - & $15 \%$ & $1 \%$ & na & na & $0 \%$ & $10 \%$ & na \\
\hline \multirow{2}{*}{ Incineration } & $\%$ & na & na & na & $2 \%$ & na & $1 \%$ & na & $39 \%$ & $5 \%$ & $5.40 \%$ \\
\hline & No. of plants & na & na & na & na & 4 & 1 & na & 4 & 3 & na \\
\hline \multirow{2}{*}{ Sanitary Landfill } & $\%$ & na & na & na & na & na & na & na & $15 \%$ & na & na \\
\hline & No. of plants & na & na & 10 & na & 8 & na & na & 1 & 91 & 17 \\
\hline \multirow{2}{*}{$\begin{array}{l}\text { Controlled } \\
\text { Landfill }\end{array}$} & $\%$ & na & na & na & na & na & na & na & - & na & na \\
\hline & No. of plants & na & na & 70 & & 10 & & 273 & - & 20 & 91 \\
\hline $\begin{array}{l}\text { Solid Waste } \\
\text { Disposal }\end{array}$ & $\%$ & $70 \%$ & $20 \%$ & $84 \%$ & $61 \%$ & $93 \%$ & $90 \%$ & $65 \%$ & $0 \%$ & $70 \%$ & na \\
\hline Others & $\%$ & $28 \%$ & $60 \%$ & $9 \%$ & $13 \%$ & $6 \%$ & $4 \%$ & $5 \%$ & $8 \%$ & $1 \%$ & na \\
\hline
\end{tabular}

Note: Recycling data for Cambodia are based on Phnom Penh only; for Laos PDR, Vientiane; and for Myanmar, Yangon. The disposal method of Vietnam is based on Hanoi. na: not accessible. 
Table 2. Waste-to-energy and biomass energy potential [1,5,7,9,22,30,46-50].

\begin{tabular}{|c|c|c|c|c|c|c|c|}
\hline Country & $\begin{array}{l}\text { Waste Generation } \\
\text { (Tons/Year) (2015) }\end{array}$ & $\begin{array}{l}\text { Waste Generation } \\
\text { (Tons/Year) (2025) }\end{array}$ & $\begin{array}{l}\text { Status of WtE } \\
\text { Technologies }\end{array}$ & $\begin{array}{l}\text { Installed WtE Capacity } \\
\text { (Landfills/AD/Incineration) }\end{array}$ & Energy Potential from Waste & $\begin{array}{l}\text { Overall Bio- Energy } \\
\text { Potential from Biomass } \\
\text { across the Country }\end{array}$ & $\begin{array}{c}\text { Overall Renewable } \\
\text { Energy Target across } \\
\text { the Country }\end{array}$ \\
\hline $\begin{array}{c}\text { Brunei } \\
\text { Darussalam }\end{array}$ & 210,000 & 202,210 & Emerging & - & - & - & $\begin{array}{l}10 \% \text { RE share in power } \\
\text { generation by } 2035^{*}\end{array}$ \\
\hline Cambodia & $1,089,000(2014)$ & - & Emerging & - & - & 18.852 (GWh/year) & $\begin{array}{l}\text { More than } 2 \mathrm{GW} \text { of } \\
\text { hydropower by } 2020\end{array}$ \\
\hline Indonesia & $22,500,060(2012)$ & $55,451,165$ & Developing & $\begin{array}{l}2 \mathrm{MW} \\
(2010)\end{array}$ & $\begin{array}{l}\text { (a) } 234 \mathrm{MW} \text { of electricity from } \\
12 \mathrm{WtE} \text { plants in } 2022 \\
\text { (b) } 7.71 \mathrm{TWh} \text { as a realizable } \\
\text { generation potential from } \\
\text { renewable municipal waste for } \\
\text { RE to } 2030 \\
\text { (c) } 810 \mathrm{MW} \text { as biomass and WtE } \\
\text { target by } 2025\end{array}$ & $\begin{array}{c}\text { Bioenergy Potential: } \\
\text { 50,000 MW }\end{array}$ & $\begin{array}{l}23 \% \text { non-renewable } \\
\text { energy share in energy } \\
\text { mix in } 2025\end{array}$ \\
\hline Laos & 77,000 & $1,516,210$ & Emerging & - & - & $>200 \mathrm{MW}$ & $\begin{array}{l}\text { 30\% RE share of total } \\
\text { energy consumption } \\
\text { by } 2025\end{array}$ \\
\hline Malaysia & $10,680,000$ & $18,854,075$ & Developing & $\begin{array}{l}\text { (a) } 13.8 \mathrm{MW} \text { (landfill biogas } \\
\text { plants during 2012-2018) } \\
\text { (b) } 5 \text { MW (incineration) }\end{array}$ & $\begin{array}{l}\text { (a) } 400 \text { MW from MSW } \\
\text { (theoretical) } \\
\text { (b) } 11.7 \text { MW (planned landfill } \\
\text { capacity from new projects) } \\
\text { (c) } 1.06 \text { TWh as a realizable } \\
\text { generation potential from } \\
\text { renewable municipal waste for } \\
\text { RE to } 2030\end{array}$ & $\begin{array}{c}\text { Bioenergy Potential: } \\
\text { 29,000 MW }\end{array}$ & $\begin{array}{l}4 \text { GW RE installed } \\
\text { capacity by } 2030^{*}\end{array}$ \\
\hline Myanmar & $1,130,040$ & $7,669,380$ & Emerging & $0.76 \mathrm{MW}$ & - & $\begin{array}{l}\text { Bio-energy potential: } \\
\text { 11,640 MW (Biomass } \\
\text { energy: } 6899 \mathrm{MW} ; \\
\text { biogas: } 4741 \mathrm{MW} \text { ) }\end{array}$ & $\begin{array}{c}15-20 \% \text { RE share in } \\
\text { installed capacity by } \\
2030^{*}\end{array}$ \\
\hline Philippines & $14,400,000$ & $28,388,240$ & Developing & - & $\begin{array}{l}\text { (a) } 3.02 \text { TWh as a realizable } \\
\text { generation potential from } \\
\text { renewable municipal waste for } \\
\text { RE to } 2030 \\
\text { (b) } 267 \text { MW by } 2030\end{array}$ & - & $\begin{array}{l}15 \mathrm{GW} \text { installed capacity } \\
\text { in } 2030^{*}\end{array}$ \\
\hline
\end{tabular}


Table 2. Cont

\begin{tabular}{|c|c|c|c|c|c|c|c|}
\hline Country & $\begin{array}{l}\text { Waste Generation } \\
\text { (Tons/Year) (2015) }\end{array}$ & $\begin{array}{l}\text { Waste Generation } \\
\text { (Tons/Year) (2025) }\end{array}$ & $\begin{array}{l}\text { Status of WtE } \\
\text { Technologies }\end{array}$ & $\begin{array}{c}\text { Installed WtE Capacity } \\
\text { (Landfills/AD/Incineration) }\end{array}$ & Energy Potential from Waste & $\begin{array}{l}\text { Overall Bio- Energy } \\
\text { Potential from Biomass } \\
\text { across the Country }\end{array}$ & $\begin{array}{c}\text { Overall Renewable } \\
\text { Energy Target across } \\
\text { the Country }\end{array}$ \\
\hline Singapore & $\begin{array}{l}\text { MSW: 7,670,000 } \\
\text { Organic Waste: } \\
\text { 1,520,000 }\end{array}$ & $3,353,255$ & Mature & $\begin{array}{l}256.8 \mathrm{MW} \text { from } 4 \\
\text { incineration plants }\end{array}$ & $\begin{array}{l}\text { (a) } 0.21 \mathrm{TWh} \text { as a realizable } \\
\text { generation potential from } \\
\text { renewable municipal waste for } \\
\text { RE to } 2030 \\
\text { (b) } 9.9 \mathrm{MW} \text { of electricity from } \\
\text { mix of waste biomass and solar } \\
\text { power (2013) } \\
\text { (c) Potentially, } 0.9 \mathrm{MW} \text { of } \\
\text { electricity and } 5.4 \mathrm{MW} \text { of heat } \\
\text { from biomass } \\
\text { co-generation plant }\end{array}$ & - & $\begin{array}{l}350 \text { MW installed } \\
\text { capacity of solar by } 2020\end{array}$ \\
\hline Thailand & $26,850,000$ & $20,685,645$ & Developing & $\begin{array}{l}\text { 44.324 MW (landfills: } 22.23 \\
\text { MW; incineration and } \\
\text { gasification: } 20.06 \mathrm{MW} ; \\
\text { biogas: } 2.034 \mathrm{MW} \text { ) }\end{array}$ & $\begin{array}{l}\text { (a) } 160 \text { MW from MSW by } 2021 \\
\text { (b) } 2.41 \text { TWh as a realizable } \\
\text { generation potential from } \\
\text { renewable municipal waste for } \\
\text { RE to } 2030\end{array}$ & $\begin{array}{c}\text { Bio energy potential: } \\
7000 \mathrm{MW}\end{array}$ & $\begin{array}{l}30 \% \text { RE share in total } \\
\text { energy consumption by } \\
2036^{*}\end{array}$ \\
\hline Vietnam & $12,800,000$ & $26,611,785$ & Developing & - & $\begin{array}{l}\text { (a) } 2.85 \mathrm{TWh} \text { as a realizable } \\
\text { generation potential from } \\
\text { renewable municipal waste for } \\
\text { RE to } 2030\end{array}$ & $\begin{array}{l}\text { Theoretical bioenergy } \\
\text { potential: } 318,630 \mathrm{MW}\end{array}$ & $\begin{array}{l}27 \text { GW RE installation in } \\
2030^{*}\end{array}$ \\
\hline
\end{tabular}




\subsection{Requirements and Considerations for Selection of Waste-to-Energy Technologies}

Whether incineration and waste-to-energy are a net positive can depend on the efficiency of the process and the energy mix that waste-to-energy is replacing, including far better pollution and dioxin filters to protect the environment and human health [22]. Most waste-to-energy projects aim to demonstrate the full-scale utilization of municipal waste through the reduction of waste flow at disposal sites, GHG reduction, resource efficiency, energy recovery, and employment creation [42]. However, there are several requirements and considerations for the selection of suitable technologies regarding waste characteristics, plant sizes, climate and seasonal variations, and economic conditions, as described in Table 3. Waste-to-energy plants such as incineration, pyrolysis, and plasma gasification ones need huge volumes of waste-above 100 tons of waste per day and, at best, 500 tons of waste per day-to sustain the continuous combustion in the furnace of boilers to produce a consistent heat to supply to boilers for steam production [32]. For waste-to-energy production, the AD process can accept a wide range of MSW volumes starting at 25 tons of waste per day, whereas landfilling needs at least a consistent volume of MSW with a capacity of above 500 tons per day to produce a steady stream of electricity supply for the grid [34].

Some advantages of waste-to-energy technology include that when well-managed, this technology has a smaller plant footprint with a smaller area of land required to operate, a reduction of need for physical waste storage, lower carbon emissions, minimal land contamination, chemically stable by-products from incineration, a higher density of energy recovery per ton of MSW, and the utilization of a domestically-available and sustainable resources for electricity production [5,24,32]. Additionally, it is good for areas with a lack of land for landfills to adopt alternative solutions in some Southeast Asian countries such as Singapore and Brunei Darussalam [22]. For the meaningful use of the produced energy, it is very desirable to use the produced heat on site, e.g., for drying biodegradable municipal waste. Control of the electricity generator and the methods of connection to the electricity grid can also play important roles.

While the calorific values of MSW in developed countries are in the range of 8.4-17 MJ/kg [52], the calorific values of the MSW in Southeast Asian countries are estimated at 5.82-10.11 MJ per $\mathrm{kg}$ in Malaysia [53], 5.163-6.121 MJ per kg in Thailand [37], 5.52-9.37 MJ per kg in Lao PDR [38], and 5.163-7.5 MJ/kg in Myanmar [13,46]. The calorific value of waste can vary with the composition of the waste and the country's economic development, consumption habits, educational standard, time, season, etc. [2,15]. As a result, some Southeast Asian countries have lower quality waste, with calorific values ranging from 5 to $11 \mathrm{MJ} / \mathrm{kg}$, especially due to major portions of organic waste and the high moisture content of the waste. Hence, a country is suited for waste-to-energy process if pretreatment processes such as bio-drying and solar drying could be carried out. Additionally, a combination of systems, such as the cooperation of solar systems for the pre-preparation of biodegradable waste before its thermal treatment or the use of excess heat and electricity in the form of accumulation (power to X), could play an important role. Additionally, a combination of AD and incineration or other disposal methods could offer more benefits for waste-to-energy process in the region. 
Table 3. A technical parameters chart for various waste-to-energy projects [32], cited from [34].

\begin{tabular}{|c|c|c|c|c|c|}
\hline \multirow{3}{*}{ Technical Parameters } & \multicolumn{5}{|c|}{ Most Suitable $(\sqrt{ })$; Moderate $(M)$; Not Suitable $(\times)$} \\
\hline & \multicolumn{5}{|c|}{ WASTE-TO-ENERGY Technologies } \\
\hline & $\begin{array}{c}\text { Anaerobic } \\
\text { Digestion (AD) }\end{array}$ & Incineration & Pyrolysis & $\begin{array}{c}\text { Plasma } \\
\text { Gasification }\end{array}$ & $\begin{array}{c}\text { Landfill Gas } \\
\text { Extraction (LFG) }\end{array}$ \\
\hline \multicolumn{6}{|c|}{ Waste Characteristics } \\
\hline $\begin{array}{c}\text { High calorific value, } \\
>1200 \mathrm{Kcal} / \mathrm{kg} \text { (or) } \\
{[5.024 \mathrm{MJ} / \mathrm{kg}]}\end{array}$ & $\times$ & $\sqrt{ }$ & $\sqrt{ }$ & $\sqrt{ }$ & $\times$ \\
\hline $\begin{array}{c}\text { High bio-degradable } \\
\text { matter, }>50 \%\end{array}$ & $\sqrt{ }$ & M & M & $\sqrt{ }$ & $\sqrt{ }$ \\
\hline Fixed carbon, $<25 \%$ & $\sqrt{ }$ & N/A & N/A & $\sqrt{ }$ & $\sqrt{ }$ \\
\hline Total inert, $>25 \%$ & $\times$ & $x$ & $x$ & $\sqrt{ }$ & M \\
\hline $\mathrm{C}: \mathrm{N}$ ratio, $20-30: 1$ & $\sqrt{ }$ & N/A & M & $\sqrt{ }$ & N/A \\
\hline $\begin{array}{c}\text { Mixed with all types of } \\
\text { waste }\end{array}$ & $\times$ & M & M & $\sqrt{ }$ & M \\
\hline \multicolumn{6}{|c|}{ Climate } \\
\hline Hot climate, $>35^{\circ} \mathrm{C}$ & $\sqrt{ }$ & $\sqrt{ }$ & $\sqrt{ }$ & $\sqrt{ }$ & $\sqrt{ }$ \\
\hline $\begin{array}{l}\text { Moderate climate, } \\
15-25{ }^{\circ} \mathrm{C}\end{array}$ & M & $\sqrt{ }$ & $\sqrt{ }$ & $\sqrt{ }$ & $\sqrt{ }$ \\
\hline $\begin{array}{l}\text { High moisture content, } \\
\qquad>55 \%\end{array}$ & $\sqrt{ }$ & $x$ & M & $\sqrt{ }$ & $x$ \\
\hline High rainfall area & $\sqrt{ }$ & $x$ & M & $\sqrt{ }$ & $x$ \\
\hline \multicolumn{6}{|c|}{ Plant Size } \\
\hline Up to $25 \mathrm{TPD}$ & $\sqrt{ }$ & $x$ & $x$ & $x$ & $x$ \\
\hline 25-50 TPD & $\sqrt{ }$ & $\times$ & $\times$ & $x$ & $x$ \\
\hline 50-100 TPD & $\sqrt{ }$ & $\times$ & $\times$ & $x$ & $\times$ \\
\hline 100-500 TPD & $\sqrt{ }$ & $\sqrt{ }$ & M & $\sqrt{ }$ & $\sqrt{ }$ \\
\hline$>500 \mathrm{TPD}$ & $\sqrt{ }$ & $\sqrt{ }$ & $\sqrt{ }$ & $\sqrt{ }$ & $\sqrt{ }$ \\
\hline \multicolumn{6}{|c|}{ Economic Condition } \\
\hline Capital cost & $\begin{array}{l}\text { Low to } \\
\text { Moderate }\end{array}$ & High & High & Very High & Very High \\
\hline Resource conservation & $\sqrt{ }$ & $\sqrt{ }$ & $\sqrt{ }$ & $\sqrt{ }$ & $\sqrt{ }$ \\
\hline $\begin{array}{l}\text { Carbon credit } \\
\text { Advantages }\end{array}$ & $\sqrt{ }$ & M & M & $\sqrt{ }$ & M \\
\hline
\end{tabular}

Note: TPD: tons per day.

Figure 8 illustrates a comparison of different waste-to-energy technologies in term of plant capacity, energy potential, capital cost, operation and maintenance $(\mathrm{O}$ and $M)$ cost, and planning-to-commissioning costs, and emissions produced from each technology. It can be seen that waste-to-energy technologies such as incineration, gasification, and pyrolysis have higher energy potentials than others, but they also have higher plant capacities, ranging from 900 to 1300 tons of waste per day for incineration and gasification. Additionally, the capital cost of these technologies is much higher, being in the range of USD 30-180 million for incineration, USD 50-80 million for plasma gasification, and USD 16-90 million for pyrolysis. Meanwhile, the $\mathrm{O}$ and $\mathrm{M}$ cost ranges approximately from USD 80 to 120 per ton of waste for incineration and from USD 80 to 150 per ton of waste for plasma gasification and pyrolysis. It has been observed that since sanitary landfills have the lowest capital and $\mathrm{O}$ and $\mathrm{M}$ costs, most Southeast Asian countries practice it as a major waste disposal method [1]. 
Additionally, the waste management cost for sanitary landfills in developing countries ranges from 10 to 45 USD per ton [12].

The emissions from an incineration plant are $1.6 \mathrm{~kg}$ of $\mathrm{CO}_{2}$ equivalent per $\mathrm{kWh}, 191.2 \mathrm{~g}$ of $\mathrm{NOx}$ per ton of waste processed, and $94.6 \mathrm{~g}$ of $\mathrm{SO}_{2}$ per ton of waste processed. Dioxin emissions from incineration plants have stringent regulations in other developing and developed countries, being limited to $1 \mathrm{ng} / \mathrm{m}^{3}$ toxic equivalent [32,54]. In the case of the thermo-chemical treatment of MSW via incineration, gasification, and pyrolysis, a facility distance of up to $10 \mathrm{~km}$ for the exposed population for all MSW incinerators still gives negative health impacts in the long-term [34]. The disposal of bottom ash and fly ash from incinerators into landfills remains a serious environmental issue due to the presence of $8-12 \%$ ferrous metals and $0.5-1.5 \%$ non-ferrous metals in such ash [32].

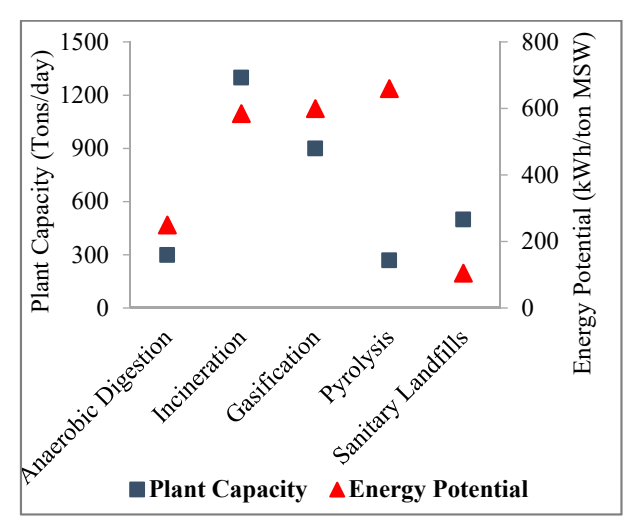

(a)

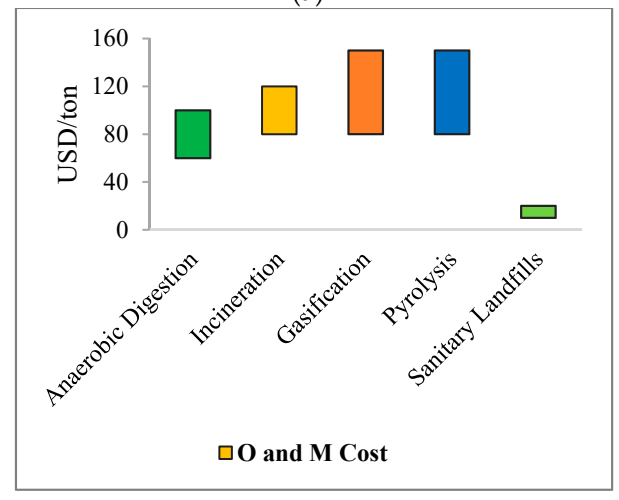

(c)

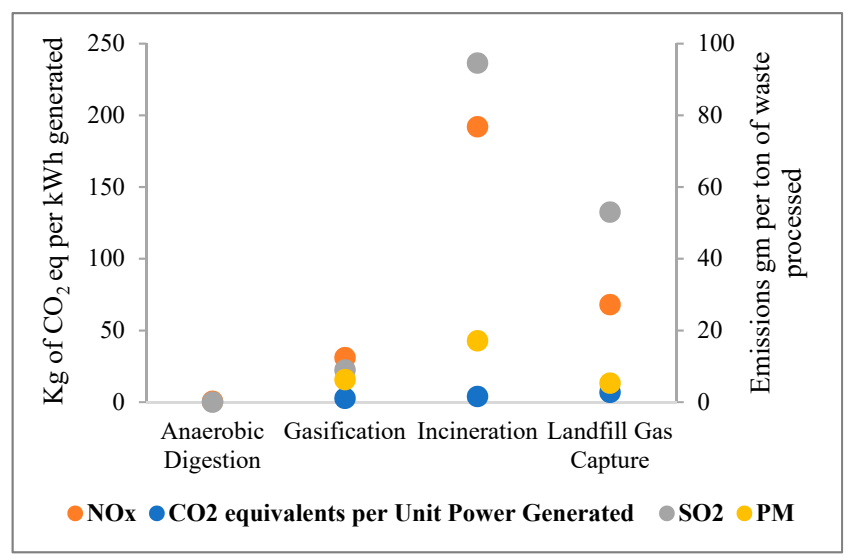

(e)

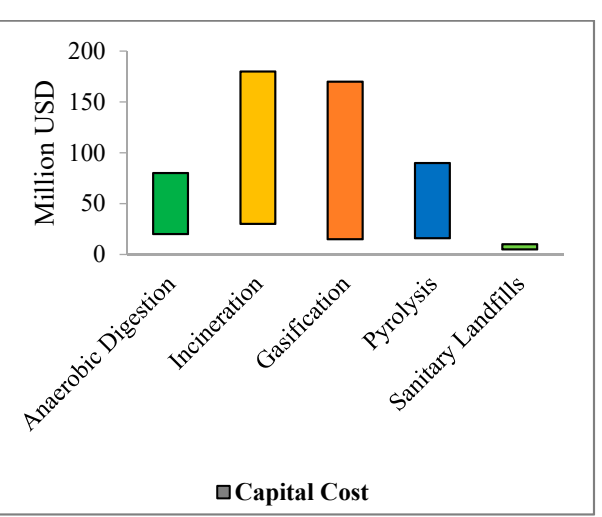

(b)

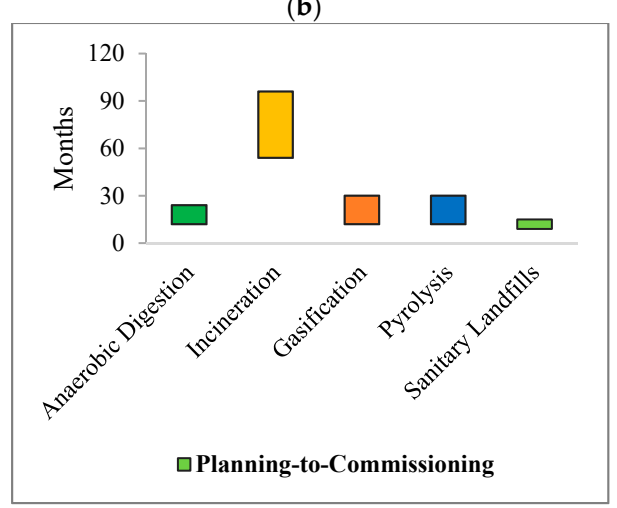

(d)

Figure 8. Comparison of different waste-to-energy technologies in term of (a) plant capacity and energy potential (b) capital cost (c) operation and maintenance $(\mathrm{O}$ and $\mathrm{M})$ cost, and (d) planning-to-commissioning cost, and (e) emissions [15,35,55]. Note: Capital cost, $\mathrm{O}$ and $\mathrm{M}$ cost, and planning-to-commissioning cost are based on plant capacity. 
However, in the case of $\mathrm{AD}$, although it is not as energy efficient as the other methods, which can yield high energy potentials with high environmental costs, the produced digestate may be beneficial to rural countries. The digestate contains a high proportion of nutrients and can be used as a fertilizer in agriculture and horticulture to avoid the use of chemical fertilizer.

\subsection{Dimensions, Challenges, Opportunities Related to Waste-to-Energy in Southeast Asia}

Based primarily on the United Nations Environment Programme (UNEP) [42] and the World Bank [1], the dimensions related to the development of waste-to-energy technologies in Southeast Asian countries are illustrated in Table 4. The 13 indicated dimensions-namely (a) policy and institutions, (b) market development, (c) the cooperation of private sector, (d) the involvement of stakeholders, (e) the knowledge level of the nations, (f) skilled personnel and training facilities, (g) public awareness, (h) data availability and reliability, (i) technology, (j) financial resources, (k) culture and climate impact, (l) the role of informal sector, and $(\mathrm{m})$ research development-are considered. It has been observed that most Southeast Asian countries, except for Singapore, Malaysia and Thailand, are at a development stage regarding the indicated dimensions. However, as mentioned above, due to the targeted promotion of renewable energy share to the total primary energy supply in each country across the region, most dimensions are expected to reach a higher degree, namely policy and institution, all stakeholder involvement, the cooperation of the private sector, and research and development. Additionally, the regionalized cooperation and collaboration among the governments of Southeast Asian countries can help enhance the development of the indicated dimensions in the region.

Table 4. Status of dimensions related to the development of waste-to-energy technologies $[1,5,9,10,12,13,22,30,42]$.

\begin{tabular}{|c|c|c|c|c|c|c|c|c|c|c|c|c|c|}
\hline Description & $\begin{array}{l}\text { Policy and } \\
\text { Institutions }\end{array}$ & $\begin{array}{c}\text { Market } \\
\text { Development }\end{array}$ & $\begin{array}{l}\text { Cooperation } \\
\text { of Private } \\
\text { Sector }\end{array}$ & $\begin{array}{c}\text { Involvement } \\
\text { of } \\
\text { Stakeholders }\end{array}$ & $\begin{array}{c}\text { Knowledge } \\
\text { Level }\end{array}$ & $\begin{array}{c}\text { Skilled } \\
\text { Personnel } \\
\text { and Training } \\
\text { Facilities }\end{array}$ & $\begin{array}{c}\text { Public } \\
\text { Awareness }\end{array}$ & $\begin{array}{c}\text { Data } \\
\text { Availability } \\
\text { and } \\
\text { Reliability }\end{array}$ & Technology & $\begin{array}{l}\text { Financial } \\
\text { Resources }\end{array}$ & $\begin{array}{l}\text { Culture and } \\
\text { Climate } \\
\text { Impact }\end{array}$ & $\begin{array}{c}\text { Role of } \\
\text { Informal } \\
\text { Sector }\end{array}$ & $\begin{array}{l}\text { Research and } \\
\text { Development }\end{array}$ \\
\hline $\begin{array}{c}\text { Brunei } \\
\text { Darussalam }\end{array}$ & L & $\mathrm{L}$ & $\mathrm{L}$ & $\mathrm{L}$ & $\mathrm{L}$ & $\mathrm{L}$ & $\mathrm{L}$ & $\mathrm{L}$ & $\mathrm{L}$ & $\mathrm{L}$ & $\checkmark$ & $\mathrm{H}$ & $\mathrm{L}$ \\
\hline Cambodia & $\mathrm{L}$ & $\mathrm{L}$ & $\mathrm{L}$ & $\mathrm{L}$ & $\mathrm{L}$ & $\mathrm{L}$ & $\mathrm{L}$ & $\mathrm{L}$ & $\mathrm{L}$ & $\mathrm{L}$ & $\sqrt{ }$ & $\mathrm{H}$ & $\mathrm{L}$ \\
\hline Indonesia & $\mathrm{M}$ & M & M & $\mathrm{L}$ & $\mathrm{L}$ & $\mathrm{L}$ & $\mathrm{L}$ & M & $\mathrm{L}$ & M & $\sqrt{ }$ & $\mathrm{H}$ & $\mathrm{L}$ \\
\hline Lao PDR & $\mathrm{L}$ & $\mathrm{L}$ & $\mathrm{L}$ & $\mathrm{L}$ & $\mathrm{L}$ & $\mathrm{L}$ & $\mathrm{L}$ & $\mathrm{L}$ & $\mathrm{L}$ & $\mathrm{L}$ & $\sqrt{ }$ & $\mathrm{H}$ & $\mathrm{L}$ \\
\hline Malaysia & M & M & M & M & $\mathrm{L}$ & $\mathrm{L}$ & $\mathrm{L}$ & M & M & M & $\sqrt{ }$ & M & M \\
\hline Myanmar & $\mathrm{L}$ & $\mathrm{L}$ & $\mathrm{L}$ & $\mathrm{L}$ & $\mathrm{L}$ & $\mathrm{L}$ & $\mathrm{L}$ & $\mathrm{L}$ & $\mathrm{L}$ & $\mathrm{L}$ & $\sqrt{ }$ & $\mathrm{H}$ & $\mathrm{L}$ \\
\hline Philippines & $\mathrm{L}$ & $\mathrm{L}$ & $\mathrm{L}$ & $\mathrm{L}$ & $\mathrm{L}$ & $\mathrm{L}$ & $\mathrm{L}$ & $\mathrm{L}$ & $\mathrm{L}$ & $\mathrm{L}$ & $\sqrt{ }$ & $\mathrm{H}$ & $\mathrm{L}$ \\
\hline Singapore & $\mathrm{H}$ & $\mathrm{H}$ & $\mathrm{H}$ & $\mathrm{H}$ & $\mathrm{H}$ & $\mathrm{H}$ & $\mathrm{H}$ & $\mathrm{H}$ & $\mathrm{H}$ & $\mathrm{H}$ & $\sqrt{ }$ & - & $\mathrm{H}$ \\
\hline Thailand & M & $\mathrm{M}$ & M & M & $\mathrm{L}$ & $\mathrm{L}$ & $\mathrm{L}$ & M & M & M & $\sqrt{ }$ & M & M \\
\hline Vietnam & M & M & $\mathrm{L}$ & $\mathrm{L}$ & $\mathrm{L}$ & $\mathrm{L}$ & $\mathrm{L}$ & $\mathrm{L}$ & $\mathrm{L}$ & $\mathrm{L}$ & $\sqrt{ }$ & $\mathrm{H}$ & M \\
\hline
\end{tabular}

Note: L: low; M: median; H: high.

A summary of challenges and opportunities related to the development of the waste-to-energy sector in the region is shown in Table 5. Four aspects were considered for challenges and opportunities-technical aspects, financial aspects, environmental aspects, and social and political aspects. On one hand, it was found that some Southeast Asian countries such as Singapore, Malaysia, and Thailand have made a reasonably successful step toward waste-to-energy technologies, but the development of the waste-to-energy sector in Cambodia, Laos PDR, and Myanmar still encounters big challenges such as a lack of policies and programs related to MSW management, limited budget allocation, a lack of co-operation between stakeholders, and a limited awareness and behavior of people related to the concept of sustainable cities/green cities. [16,42]. Hence, most of the challenges are often complicated, and it may take a long time to create large-scale waste-to-energy processes in these countries.

On the other hand, there are several favorable opportunities that can be had from waste-to-energy technologies. These opportunities account for renewable energy supply, resource conservation, revenue, profits, carbon credits, inclusive growth, community empowerment, green job creation, enterprise development, and education and training opportunities for vocational education, etc. [2,15,32,42]. The key drivers for overcoming the challenges and opening opportunities in the region are the movement to the green and sustainable cities, changes of government policy and regulations, regionalized cooperation and coordination among the governments, all stakeholder involvement, public-private partnerships, and cooperation with international organizations including the UNEP, 
the World Bank, and the International Renewable Energy Agency (IRENA). The movement can also affect public awareness and participation, cleaning and greening, resource conservations, and climate actions.

Table 5. Summary of challenges and opportunities related to the development of the waste-to-energy sector in the region $[2,11,12,15,16,30,32,36,40,42,43]$.

\begin{tabular}{|c|c|}
\hline Challenges & Opportunities \\
\hline \multicolumn{2}{|c|}{ Technical Aspects } \\
\hline $\begin{array}{l}\text { - } \text { Quality of waste } \\
\text { - } \text { Quantity of waste } \\
\text { - } \text { Continuous supply of waste } \\
\text { - } \text { Local skilled personnel and experts } \\
\text { - } \text { Incompetent local operators } \\
\text { - } \text { tropical or sub-tropical zone } \\
\text { - } \quad \text { Stringact of seasonal variations } \\
\text { - } \quad \text { incinerator) } \\
\text { Policy and regulatory issues }\end{array}$ & $\begin{array}{l}\text { - Technology transfer from the developed countries } \\
\text { - } \text { cessons learned and best practices from the other } \\
\text { - Choice of appropriate technologies regarding the } \\
\text { - } \text { locally available resources } \\
\text { - Imprgy security and reduced emissions } \\
\text { - A small area to operate } \\
\text { - Highly efficient solution for urban areas with land } \\
\text { - } \text { Ecarcity and a high energy demand } \\
\text { education and training opportunities for vocational }\end{array}$ \\
\hline \multicolumn{2}{|r|}{ Financial Aspects } \\
\hline $\begin{array}{l}\text { - } \text { Waste and electricity management } \\
\text { - } \text { Initial and operation cost } \\
\text { - } \text { High O and M cost } \\
\text { - } \text { Insufficient local expertise } \\
\text { - } \quad \text { Ponding constraints } \\
\text { - } \quad \text { Financial assistance }\end{array}$ & $\begin{array}{l}\text { - } \text { Revenue, profits and carbon credits } \\
\text { - } \text { Public-private partnership } \\
\text { - } \text { Stakeholder incentivizing and stakeholder } \\
\text { involvement } \\
\text { - } \text { Green job creation and enterprise development } \\
\text { - } \text { Investment in MSW sector } \\
\text { - } \text { Local economy growth }\end{array}$ \\
\hline \multicolumn{2}{|c|}{ Environmental Aspects } \\
\hline $\begin{array}{l}\text { - } \text { Residual management } \\
\text { - } \text { Emission management } \\
\text { - } \text { Location of facilities } \\
\text { - } \text { manironmental pollution if not well } \\
\text { - Policy and regulatory issues }\end{array}$ & $\begin{array}{l}\text { - Reduction of waste volume and disposal sites } \\
\text { - } \text { managed } \\
\text { - } \text { Reduction of GHG emissions } \\
\text { - } \text { Sustainable management } \\
\text { environment }\end{array}$ \\
\hline \multicolumn{2}{|c|}{ Social and Political Aspects } \\
\hline 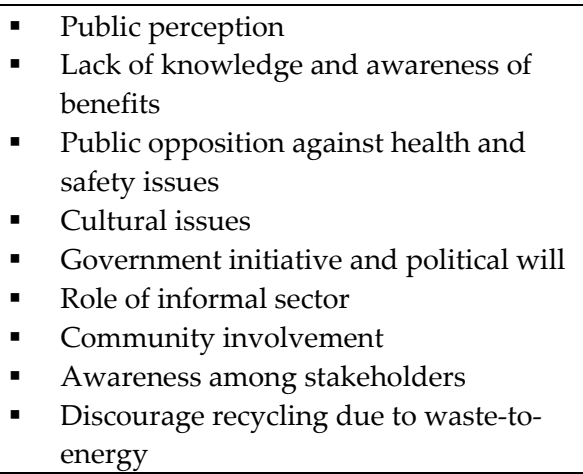 & $\begin{array}{l}\text { - } \text { Stakeholder involvement and public participation in } \\
\text { - } \text { order for sustainable green cities } \\
\text { - } \text { Eolitical interests for sustainable development goals } \\
\text { - } \text { community and private sector engagements } \\
\text { - } \text { Pevelopment of policy and regulations } \\
\text { - Prevention of diseases and health hazards } \\
\text { - } \text { Inclusive growth and community empowerment }\end{array}$ \\
\hline
\end{tabular}

\section{Recommendations for the Way Forward}

The governments of Southeast Asian countries have set targets for renewable energy usage by 2025 to speed up the pace of sustainable energy development [39]. Regarding energy from waste, it is expected that the waste-to-energy market across the region will continue growing due to the following reasons $[2,9,15]$ : 
(i) An increase in waste generation due to rapid urbanization.

(ii) Supportive governmental actions (e.g., policies, taxes, and subsides).

(iii) The need to increase the share of renewable energy sources.

(iv) The development of new waste-to-energy technologies.

(v) The growth of the market in developed countries leading to a reduction of the cost for the technologies from which developing countries would benefit.

(vi) The benefits from waste-to-energy facilities in terms of employment and educational opportunities.

(vii) Energy security and reduced environmental pollutions

(viii) The development of technologies adapted to local needs, as well as the development of tri-generation cooperation.

There could be some multi-criteria decision analysis methods to follow and enable environmental decision making and sustainable energy planning regarding the development of the waste-to-energy sector. The decision matrix parameters for the selection of waste-to-energy technologies suited for specific countries are illustrated in Figure 9. There are 12 parameters that need to be considered before suitable waste-to-energy technologies are selected or implemented in a country.

(a) The existence of an advanced waste management system (Does it exist? If it does, how to manage its development?).

(b) Waste quality and quantity (If available, how is it maintained? If not, how to improve/supply it?).

(c) Climate and seasonal variations (How much/how often do they affect waste management?).

(d) Viable market availability (If it exists, how to promote it? If not, how to create it?).

(e) Transport time and distance to plants (If the plants exist, which ways of transport are best? If not, how to manage their development?).

(f) Legal framework and environmental requirements (If available, how to upgrade them? If not, how to make/fulfil them?).

(g) Access to energy end-users and spare parts of waste-to-energy technologies (If available, how to promote them? If not, how to create access to them?).

(h) Finance resources (If available, how to maintain them? If not, how to create necessary funds?).

(i) Cooperation of the private sector (If available, how to promote it? If not, how to cooperate/offer incentives?).

(j) All stakeholder involvement (If it exists, how to promote it? If not, how to manage its development?)

(k) Public awareness and participation (If active, how to promote it? If not, how to manage/educate the population?)

(1) Ensured promotion of capacity building (If available, how to maintain it? If not, how to train/share?)

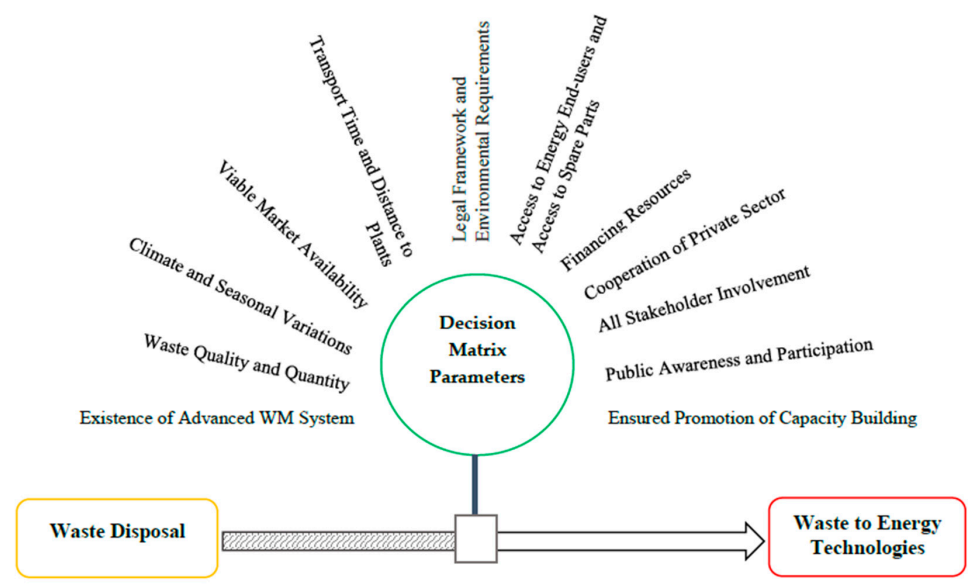

Figure 9. An approach to the selection of waste-to-energy technologies by decision matrix parameters $[13,28,32]$. 
A basic requirement for the successful implementation of waste-to-energy technology is the existence of an advanced waste management system that helps to improve the separate collection and treatment of different separated waste streams [16]. International and regional organizations like the Asian Development Bank, the World Bank, and the Asia-Pacific Economic Cooperation (APEC) play serious roles in the sustainable green energy development in the Southeast Asian region, and grass root organizations should use appropriate business models when utilizing these welfare schemes [39]. To achieve a viable risk structure for waste-to-energy projects, initiatives will require close coordination and cooperation among multiple government stakeholders, including the state utility as an off-taker of electricity, municipalities for a supply of waste, and land sites to achieve a bankable PPP structure that ensures a stable and predictable cash flow for waste-to-energy plants [22].

Currently, due to limited capacity in the renewable energy technology manufacturing and servicing sectors and a lack of skilled technicians for the installation and maintenance of technologies, training and research and development programs need to be well-developed [7] in order to overcome the barriers against the development of waste-to-energy technologies. Likewise, economic feasibility regarding the development of the waste-to-energy sector should be based on affordable gate fees and electricity fed-in tariffs if applicable [22]. It has also been observed that the role of the private sector participation in retail and wholesale markets is crucial for the development and productivity of the overall MSW management system [56] Since Singapore and other countries in the region are setting the right benchmarks for the development of waste-to-energy projects, successful projects can serve as templates for other countries in the region [22].

In Southeast Asia, climate and seasonal variations, especially in the rainy season, could affect the quality and quantity of waste to a reasonable extent. In such case, bio-drying and other drying options from locally available energy sources or a combination of drying processes would be a possible way to pretreat waste to maintain the sustained quality of waste input into the waste-to-energy process.

In most developing countries, the implementation of most incineration plants fails due to low calorific values of waste, high moisture contents of waste, high operational and maintenance costs, and sorting issues $[32,33,54]$. Therefore, the involvement of local people in proper sorting and pretreatment methods will be most helpful to effectively implement plants. However, a better scenario is a combination of $\mathrm{AD}$ and incineration or other disposal methods for an effective waste-to-energy process. Since policy frameworks and regulations related to MSW management systems in most developing countries need to be integrated and improved, the implementation of programs could not be effectively and efficiently carried out [42]. Hence, policies and regulations can play important roles in achieving the targets and sustainability of the projects $[12,42,57]$.

Finally, since China has developed a large quantity of energy production from waste [5], three lessons can be learned from China. Those three lessons [5] are: (a) a short-term solution for incineration that can manage the waste crisis, and a long-term solution is to establish effective waste sorting systems suitable for the best waste-to-energy technologies; (b) moving beyond traditional incineration is important for the sustainable operation of plants and the effective use of resources; and (c) even China faces environmental pushback over the impacts of waste-to-energy technologies, so Southeast Asian countries may also face universal pushbacks. With these lessons learned, the countries can work until the sustainable operation and effective utilization of resources are ensured. Therefore, learning lessons from others and gaining technology transfer and market development from developed countries will help Southeast Asian countries take a better step towards waste-to-energy processes in the near future. The implementation of waste-to-energy plants could be good solution to the harmful emissions of landfills. Fluidized bed conversion technologies are also very suitable for the waste with higher contents of water.

\section{Conclusions}

This study is an overview of the waste-to-energy sector in Southeast Asian countries that specifies the status, challenges, opportunities, and selections of waste-to-energy technologies suited for each 
specific country. Since most countries in Southeast Asia are developing countries, where their MSW management systems are at the development stage, there is limited access to updated data about MSW management system and the waste-to-energy sector. However, in order to achieve its aim, the researchers collected data to as much as they could. It was observed that the total quantity of the capacity from landfill biogas plants, incineration plants, and other waste-to-energy practices in the region accounts for over $323 \mathrm{MW}$ at present and is expected to double by 2022. Additionally, by 2030, the realizable generation potential from renewable municipal waste in six Southeast Asian countries (Indonesia, Malaysia, Philippines, Singapore, Thailand, and Vietnam) will amount to 17.26 TWh. In this study, four aspects were considered for challenges and opportunities for the development of waste-to-energy technologies. Regarding these aspects, several big challenges of waste-to-energy technology across the region were found to complicated. There are also several favorable opportunities affording by these technologies, including renewable energy supplies, resource conservation, revenue, profits, and carbon credits. The key drivers for overcoming challenges and opening opportunities in the region are the movement to the green and sustainable cities, changes of government policy and regulations, regionalized cooperation and coordination among the governments, all the stakeholder involvement, public-private partnerships, cooperation with international organizations including the UNEP, the World Bank, and the IRENA. Likewise, the selection of waste-to-energy technologies is crucial for a specific country, so our decision matrix parameters and technical parameters chart for various waste-to-energy projects will be very helpful to specify whether targets are achievable. There could also be some multi-criteria decision analysis methods to follow and enable environmental decision making and sustainable energy planning. Finally, learning lessons from others and gaining technology transfers and market development from developed countries can help Southeast Asian countries take a better step towards waste-to-energy processes in the near future.

Author Contributions: Conceptualization, methodology, and resources, M.M.T. and D.J.; formal analysis and investigation, M.M.T., D.J., P.P., and V.S.; supervision, D.J.; writing-original draft preparation, M.M.T.; writing-review and editing, M.M.T., D.J., P.P., and V.S. All authors have read and agreed to the published version of the manuscript.

Funding: The study was funded by Ministry of Education, Youth and Sports of the Czech Republic—Involvement of Czech Research Organizations in the European Alliance for Energy Research EERA LTI19002.

Acknowledgments: The author would like to express his special gratitude to Ministry of Education, Youth and Sports of the Czech Republic, as well as Ministry of Education of Myanmar for giving him an opportunity to study in the Czech Republic.

Conflicts of Interest: The authors declare no conflict of interest.

\section{References}

1. Hoornweg, D.; Bhada-Tata, P. What a Waste: A Global Review of Solid Waste Management; Urban Development Series; Knowledge Papers No. 15; World Bank: Washington, DC, USA, 2012.

2. Edo, M.; Johansson, I. International perspectives of energy from waste-Challenges and trends. In Proceedings of the IRRC Waste-to-Energy Conference, Vienna, Austria, 1-2 October 2018.

3. International Energy Agency (IEA). Waste-to-Energy. Summary and Conclusions from the IEA Bioenergy ExCo71 Workshop; ExCo:2014:03; IEA Bioenergy: Vienna, Austria, 2013; pp. 1-24.

4. Curea, C. Sustainable societies and municipal solid waste management in Southeast Asia. In Sustainable Asia: Supporting the Transition to Sustainable Consumption and Production in Asian Developing Countries; Schroeder, P., Anggraeni, K., Sartori, S., Weber, U., Eds.; World Scientific Publishing Company: Singapore, 2017; pp. 391-415.

5. Weatherby, C. Waste-to-Energy: A Renewable Opportunity for Southeast Asia? Available online: https:// chinadialogue.net/en/energy/11093-waste-to-energy-a-renewable-opportunity-for-southeast-asia/ (accessed on 5 July 2020).

6. International Energy Agency (IEA). Energy Balances of Non-OECD Countries; IEA/OECD: Paris, France, 2009.

7. Ölz, S.; Beerepoot, M. Deploying Renewables in Southeast Asia: Trends and Potentials; International Energy Agency: Paris, France, 2010; pp. 7-157. 
8. Bakhtyar, B.; Sopian, K.; Sulaiman, M.Y.; Ahmad, S.A. Renewable Energy in Five South East Asian Countries: Review on Electricity Consumption and Economic Growth. Renew. Sustain. Energy Rev. 2013, 26, 506-514. [CrossRef]

9. Tun, M.M.; Juchelkova, D.; Win, M.M.; Thu, A.M.; Puchor, T. Biomass energy: An overview of biomass sources, energy potential, and management in Southeast Asian countries. Resources 2019, 8, 81. [CrossRef]

10. Tun, M.M.; Juchelkova, D. Biomass Sources and Energy Potential for Energy Sector in Myanmar: An Outlook. Resources 2019, 8, 102. [CrossRef]

11. Damen, B. Sustainable Bioenergy in Southeast Asia An FAO Perspective. Available online: www.fao.org/ bioenergy/en/ (accessed on 5 July 2020).

12. Modak, P.; Pariatamby, A.; Seadon, J.; Bhada-Tata, P. International Solid Waste Association. Asia Waste Management Outlook; United Nations Environment Programme: Manama, Bahrain, 2017.

13. Tun, M.M.; Juchelková, D.; Raclavská, H.; Sassmanová, V. Utilization of biodegradable wastes as a clean energy source in the developing countries: A case study in Myanmar. Energies 2018, 11, 3183. [CrossRef]

14. Ecoprog. Waste-to-Energy 2016/2017. Technologies, Plants, Projects and Backgrounds of the Global Thermal Waste Treatment Business (Extract). 2016. Available online: https://www.ecoprog.com/fileadmin/user_ upload/extract_market_report_WtE_2019-2020_ecoprog.pdf (accessed on 6 July 2020).

15. Marshall, J.; Hoornweg, D.; Eremed, W.B.; Piamonti, G. World Energy Resources Waste-to-Energy; World Energy Council: London, UK, 2016; pp. 5-60. ISBN 978-0-946121-58-8.

16. RPG Group. Project Proposal: Waste-to-Energy Technology, Policy and Investment Perspective. Raymond Tech Australia. Available online: http://www.raymondtech.com.au/docs/Waste_to_Energy\%20Proposal. pdf (accessed on 5 July 2020).

17. Hoang, N.H.; Fogarassy, C. Sustainability Evaluation of Municipal Solid Waste Management System for Hanoi (Vietnam) -Why to Choose the 'Waste-to-Energy' Concept. Sustainability 2020, 12, 1085. [CrossRef]

18. Tun, M.M.; Juchelková, D. Problems with Biodegradable Wastes-Potential in Myanmar and Other Asian Countries for Combination of Drying and Waste Incineration. In Proceedings of the IRRC Waste-to-Energy Conference, Vienna, Austria, 1-2 October 2018.

19. Kreith, F. Waste to Energy Combustion. In Handbook of Solid Waste Management, 2nd ed.; Tchobanoglous, G., Kreith, F., Eds.; McGraw-Hill: New York, NY, USA, 2002; pp. 1-176.

20. Tomohiro, T. In: Waste-to-energy incineration plants as greenhouse gas reducers: A case study of seven Japanese metropolises. Waste Manag. Res. 2013, 31, 1110-1117.

21. European Suppliers of Waste-to-Energy Technology (ESWET). Everything You Always Wanted to Know about Waste-to-Energy. Available online: http://www.eswet.eu/tl_files/eswet/5.\%20Documents/5.1.\%20Waste-toEnergy\%20Handbook/ESWET_Handbook_Waste-to-Energy.pdf (accessed on 7 August 2020).

22. Lim, W.B.; Yuen, E.; Bhaska, A.R. Waste-to-Energy: Green Solutions for Emerging Markets. 2019. Available online: https:/home.kpmg/xx/en/home/insights/2019/10/waste-to-energy-green-solutions-for-emergingmarkets.html (accessed on 9 August 2020).

23. Ouda, O.K.M.; Raza, S.A. Waste-to-Energy: Solution for Municipal Solid Waste Challenges-Global Perspective. In Proceedings of the 2014 International Symposium on Technology Management and Emerging Technologies, Bandung, Indonesia, 27-29 May 2014.

24. Tun, M.M.; Juchelková, D. Drying Methods for Municipal Solid Waste Quality Improvement in the Developed and Developing Countries: A Review. Environ. Eng. Res. 2019, 24, 529-542. [CrossRef]

25. Brunner, P.H.; Rechberger, H. Waste-to-energy-Key element for sustainable waste management. Waste Manag. 2015, 37, 3-12. [CrossRef]

26. Di Matteo, U.; Nastasi, B.; Albo, A.; Astiaso Garcia, D. Energy contribution of OFMSW (Organic Fraction of Municipal SolidWaste) to energy-environmental sustainability in urban areas at small scale. Energies 2017, 10, 229. [CrossRef]

27. Choudhury, A.R. Environmental Sustainability: Coping with Raising Volume of Urban Waste. Available online: www.ramkyenviroengineers.com (accessed on 7 July 2020).

28. Mutz, D.; Hengevoss, D.; Hugi, C.; Gross, T. Waste-to-Energy Options in Municipal Solid Waste Management a Guide for Decision Makers in Developing and Emerging Countries; Deutsche Gesellschaft für Internationale Zusammenarbeit (GIZ) GmbH: Eschborn, Germany, 2017.

29. Intharathirat, R.; Salam, P.A. Valorization of MSW-to-energy in Thailand: Status, challenges and prospects. Waste Biomass Valorization 2016, 7, 31-57. [CrossRef] 
30. Jacob, P.; Kashyap, P.; Visvanathan, C. Overview of municipal solid waste-Waste-to-energy in Thailand. International Brainstorming on Waste to Energy in India, Mumbai, India, 25 June 2013. [CrossRef]

31. Tan, S.T.; Ho, W.S.; Hashim, H.; Lee, C.T.; Taib, M.R.; Ho, C.S. Energy, economic and environmental (3E) analysis of waste-to-energy (WTE) strategies for municipal solid waste (MSW) management in Malaysia. Energy Convers. Manag. 2015, 102, 111-120. [CrossRef]

32. Yong, Z.J.; Bashir, M.J.; Ng, C.A.; Sethupathi, S.; Lim, J.W.; Show, P.L. Sustainable Waste-to-Energy Development in Malaysia: Appraisal of Environmental, Financial, and Public Issues Related with Energy Recovery from Municipal Solid Waste. Processes 2019, 7, 676. [CrossRef]

33. Aja, O.C.; Al-Kayiem, H.H. Review of municipal solid waste management options in Malaysia, with an emphasis on sustainable waste-to-energy options. J. Mater. Cycles Waste Manag. 2014, 16, 693-710. [CrossRef]

34. Aich, A.; Ghosh, S.K. Application of SWOT analysis for the selection of technology for processing and disposal of MSW. Procedia Environ. Sci. 2016, 35, 209-228. [CrossRef]

35. Zaman, A.U. Life cycle environmental assessment of municipal solid waste-to-energy technologies. Glob. J. Environ. Res. 2009, 3, 155-163.

36. Tien, N.H. Integrated Solid Waste Management in Viet Nam. Presentation. Available online: http://wadassdi.web. fc2.com/vwp/ws1/1tien_en.pdf (accessed on 17 August 2020).

37. Kaosol, T. In: Sustainable solutions for municipal solid waste management in Thailand. World Acad. Sci. Eng. Technol. 2009, 60, 665-670.

38. Sisoulath, B. Solid Waste Management in Lao PDR. In Proceedings of the Second Meeting of the Regional 3R Forum in Asia, Kuala Lumpur, Malaysia, 4-6 October 2010.

39. Erdiwansyah Mamat, R.; Sani, M.S.; Sudhakar, K.J. Renewable energy in Southeast Asia: Policies and recommendations. Sci. Total Environ. 2019, 670, 1095-1102. [CrossRef]

40. Moya, D.; Aldás, C.; López, G.; Kaparaju, P. Municipal solid waste as a valuable renewable energy resource: A worldwide opportunity of energy recovery by using Waste-To-Energy Technologies. Energy Procedia 2017, 134, 286-295. [CrossRef]

41. Veng, V.; Suryadi, B.; Pranadi, A.D.; Shani, N. A review of renewable energy development and its policy under nationally determined contributions in ASEAN. Int. J. Smart Grid Clean Energy 2020, 9, 1. [CrossRef]

42. United Nations Environment Programme. Summary Report: Waste Management in ASEAN Countries, Thailand; United Nations Environment Programme: Nairobi, Kenya, 2017; p. 7. Available online: https://www. unenvironment.org/resources/report/waste-management-asean-countriessummary-report (accessed on 9 August 2020).

43. International Renewable Energy Agency (IRENA). Renewable Energy Market Analysis: Southeast Asia; IRENA: Abu Dhabi, UAE, 2018; pp. 9-158. ISBN 978-92-9260-056-3.

44. IRENA; ACE. Renewable Energy Outlook for ASEAN: A REmap Analysis; International Renewable Energy Agency (IRENA), Abu Dhabi and ASEAN Centre for Energy (ACE): Jakarta, Indonesia, 2016.

45. Economic Research Institute for ASEAN and East Asia (ERIA). Chapter 2: The Potential of Distributed Energy System from Renewable Energy in ASEAN; ERIA: Jakarta, Indonesia; pp. 14-34. Available online: https:/www.eria.org/uploads/ media/2_The_Potential_of_Distributed_Energy_System_from_Renewable_Energy_in_ASEAN.pdf (accessed on 10 August 2020).

46. JFE Engineering Corporation. Opening Ceremony for Myanmar's First Waste-to-Energy Plant. Available online: https://www.jfe-eng.co.jp/en/news/2017/20170410.html (accessed on 10 August 2020).

47. Global Energy Observatory. Keppel Seghers Tuas WTE Plant, Singapore. Available online: http: //globalenergyobservatory.org/form.php?pid=3828 (accessed on 14 September 2020).

48. Global Energy Observatory, Senoko WTE Incineration Plant, Singapore. Available online: http://globalenergyobservatory. org/form.php?pid=42427 (accessed on 14 September 2020).

49. National Environmental Agency (NEA), Singapore. Tuas South Incineration Plant, Singapore. Available online: https://web.archive.org/web/20160922174351/http://www.nea.gov.sg/energy-waste/waste-management/refusedisposal-facility (accessed on 14 September 2020).

50. Department of Alternative Energy Development and Efficiency (DAEDE). Thailand Needs to Promote Energy-from-Waste. Available online: http://weben.dede.go.th/webmax/content/thailand-needs-promoteenergy-waste (accessed on 10 August 2020).

51. The World Bank. GDP per Capita (Current US \$). Available online: https://data.worldbank.org/indicator/NY. GDP.PCAP.CD?end=2015\&name_desc=true\&start=2005\&view=chart (accessed on 15 August 2020). 
52. Cheng, H.; Hu, Y. Municipal solid waste (MSW) as a renewable source of energy: Current and future practices in China. Bioresour. Technol. 2010, 101, 3816-3824. [CrossRef]

53. Hassan, M.N.; Chong, T.L.; Rahman, M.; Salleh, M.N.; Zakaria, Z. Awang, MSolid waste management in Southeast Asian countries with special attention to Malaysia. In Proceedings of the Sardinia, 8th International Waste Management and Landfill Symposium, Cagliari, Italy, 1-5 October 2001.

54. Elliott, C.; Campbell, A.; Balen, E.V. Health Assessment for Thermal Treatment of Municipal Solid Waste in British Columbia: Evidence Review and Recommendations; British Columbia Centre for Disease Control (BCCDC): Vancouver, BC, Canada, 2012.

55. Zafar, S. Comparison of Different Waste-to-Energy Processes. Connecting Energy with Environment, Clean Energy Solutions. September 2011. Available online: https://cleantechsolutions.wordpress.com/2011/ 09/24/comparison-of-different-waste-to-energy-processes/ (accessed on 3 August 2020).

56. Simões, P.; Da Cruz, N.; Marques, R. The performance of private partners in the waste sector. J. Clean. Prod. 2012, 29, 214-221. [CrossRef]

57. Simões, P.; Marques, R. Influence of regulation on the productivity of waste utilities. What can we learn with the Portuguese experience? Waste Manag. 2012, 32, 1266-1275. [CrossRef] [PubMed]

Publisher's Note: MDPI stays neutral with regard to jurisdictional claims in published maps and institutional affiliations.

(C) 2020 by the authors. Licensee MDPI, Basel, Switzerland. This article is an open access article distributed under the terms and conditions of the Creative Commons Attribution (CC BY) license (http://creativecommons.org/licenses/by/4.0/). 